\title{
Taking the strain out of onchocerciasis? A reanalysis of blindness and transmission data does not support the existence of a savannah blinding strain of onchocerciasis in West Africa
}

\author{
Robert A. Cheke ${ }^{*, \dagger, 1}$, Kirsty E. Little ${ }^{\ddagger}$, Stephen Young* , Martin Walker ${ }^{\Uparrow}$, \\ Maria-Gloria Basáñez ${ }^{\dagger, \S, 1}$
}

* Natural Resources Institute, Department of Agriculture, Health \& Environment, University of Greenwich at Medway, Central Avenue, Chatham Maritime, Kent, ME4 4TB, UK

${ }^{\dagger}$ London Centre for Neglected Tropical Disease Research, Department of Infectious Disease Epidemiology, Faculty of Medicine (St Mary's campus), Imperial College London, Norfolk Place, London W2 1PG, UK

$\$$ Public Health Wales, PO Box 108, Building 1, St. David's Park, Job's Well Road, Carmarthen, SA31 $3 \mathrm{WY}, \mathrm{UK}$

II London Centre for Neglected Tropical Disease Research, Department of Pathobiology and Populations Sciences, Royal Veterinary College, Hatfield, UK, AL9 7TA

$\S$ Medical Research Council for Global Infectious Disease Analysis, Department of Infectious Disease Epidemiology, Faculty of Medicine (St Mary's campus), Imperial College London, Norfolk Place, London W2 1PG, UK

Corresponding author: e-mail address: m.basanez@imperial.ac.uk

1 These authors contributed equally to the work

\section{Contents}

1. Introduction 4

1.1 Distribution and disease burden 5

1.2 Onchocerca volvulus strains and Onchocerca-Simulium complexes 6

1.3 Revisiting the forest-savannah strain hypothesis and review aims 11

2. Methods $\quad 12$

2.1 Inclusion criteria for studies in West Africa 12

2.2 Standardization of prevalence by age and sex 13

2.3 Standardization of incubation period and media for skin snips 14

2.4 Cytotaxonomic and habitat classifications $\quad 15$

$\begin{array}{ll}2.5 \text { Statistical analyses } & 16\end{array}$ 
3.1 All causes of blindness

3.2 Blindness due to onchocerciasis

3.3 Bilateral blindness

3.4 Forest blindness

3.5 Transmission intensity and microfilarial prevalence

\title{
4. Discussion
}

4.1 Transmission intensity and locally-adapted Onchocerca-Simulium populations

4.2 Onchocerca volvulus (and its Wolbachia endosymbiont) genetics

4.3 Age, sex and individual exposure patterns

\section{Conclusions and Recommendations}

5.1 Implications for onchocerciasis control and elimination programmes

Acknowledgements

\begin{abstract}
Onchocerciasis (also known as 'river blindness'), is a neglected tropical disease (NTD) caused by the (Simulium-transmitted) filarial nematode Onchocerca volvulus. The occurrence of 'blinding' (savannah) and non-blinding (forest) parasite strains and the existence of corresponding, locally-adapted Onchocerca-Simulium complexes were postulated to explain greater blindness prevalence in savannah than in forest foci. As a result, the World Health Organization (WHO) Onchocerciasis Control Programme in West Africa (OCP) focused antivectorial and anti-parasitic interventions in savannah endemic areas. In this paper, villagelevel data on blindness prevalence, microfilarial prevalence, and transmission intensity (measured by the annual transmission potential, the number of infective, L3, larvae per person per year) were extracted from 16 West-Central Africa-based publications, and analysed according to habitat (forest, forest-savannah mosaic, savannah) to test the dichotomous strain hypothesis in relation to blindness. When adjusting for sample size, there were no statistically significant differences in blindness prevalence between the habitats (oneway ANOVA, $\mathrm{P}=0.68$, mean prevalence for forest $=1.76 \pm 0.37$ (S.E.); mosaic $=1.49 \pm$ 0.38 ; savannah $=1.89 \pm 0.26$ ). The well-known relationship between blindness prevalence and annual transmission potential for savannah habitats was confirmed and shown to hold for (but not to be statistically different from) forest foci (excluding data from southern Côte d'Ivoire, in which blindness prevalence was significantly lower than in other West African forest communities, but which had been the focus of studies leading to the strain-blindness
\end{abstract}


hypothesis that was accepted by OCP planners). We conclude that the evidence for a savannah blinding onchocerciasis strain in simple contrast with a non-blinding forest strain is equivocal. A re-appraisal of the strain hypothesis to explain patterns of ocular disease is needed to improve understanding of onchocerciasis epidemiology and disease burden estimates in the light of the WHO 2030 goals for onchocerciasis.

Keywords: onchocerciasis; Onchocerca volvulus; savannah strain; forest strain; blindness prevalence; microfilarial prevalence; Simulium damnosum s.l.; annual transmission potential; West Africa 


\section{INTRODUCTION (14,144 words with abstract, text, refs)}

Onchocerciasis, also known as river blindness, is a neglected tropical disease (NTD) caused by the filarial nematode Onchocerca volvulus (Leuckart 1893) and is spread from person to person by the bites of infective vector blackflies of the genus Simulium Latreille 1802. (The term infective vectors refers to blackflies carrying the parasite stages that are infective to humans, i.e. infective or L3 larvae, which develop within the thoracic muscles of the fly from ingested microfilariae and migrate to the fly's mouthparts; see Figure 1 for a schematic representation of the parasite's life cycle.) In West Africa the vectors are members of the S. damnosum sensu lato (s.l.) species complex. This complex also has representatives that transmit elsewhere in Africa and in Yemen but in some areas in eastern and central Africa, such as Uganda and Tanzania, the vectors are members of the S. neavei s.l. complex. One of the most serious outcomes of onchocerciasis is bilateral blindness, but the infection also causes skin disease (Murdoch et al., 1993), and is associated with excess human mortality (Pion et al., 2002; Little et al., 2004b; Walker et al., 2012) and with epilepsy (Colebunders et al., 2019). Figure 1 also illustrates some of the clinical manifestations of onchocerciasis. Table 1 compares ocular manifestations due to trachoma (caused by the bacterium Chlamydia trachomatis) and loiasis (African eye-worm, caused by the filarial nematode Loa loa) with those of onchocerciasis. Onchocerciasis ocular and cutaneous morbidity is mainly due to the death of, and subsequent inflammatory responses around, the larval progeny (microfilariae) of the adult worms (reviewed in Bradley et al., 2005), with components from both the filariae and their Wolbachia pipientis endobacteria contributing to the pathogenesis of onchocerciasis (Brattig, 2004). Adult parasites (macrofilariae) reside in onchocercomata, i.e. nodules formed by fibrous host tissue around male and female worms, and which can be subcutaneous and palpable, or deep-lying and impalpable (Nnochiri, 1964; Duke, 1993). 


\section{[Insert Figure 1 and Table 1 about here]}

\subsection{Distribution and disease burden}

Onchocerciasis is endemic in 31 sub-Saharan African countries, 11 of which were under the umbrella of the World Health Organization (WHO) Onchocerciasis Control Programme in West Africa (OCP) (World Health Organization, 1995) from 1974 to 2002, and 20 were covered by the WHO African Programme for Onchocerciasis Control (APOC) (Zouré et al., 2014) from 1995 to 2015. In 2005, it was estimated that 37 million people carried O. volvulus, with 90 million at risk in Africa, where 99 percent of all cases occur (African Programme for Onchocerciasis Control, 2005; Basáñez et al., 2006). Before the inception of APOC, it was estimated that in the endemic areas under this programme, 404,000 people $(0.6 \%)$ were blind because of onchocerciasis, and another $889,000(1.2 \%)$ suffered from visual impairment (Coffeng et al., 2013). Modelling of data from the 2013 Global Burden of Disease Study revised estimates of the number of people at risk suggesting that 198 million people live in areas where there is potential for transmission of the parasite (Herricks et al., 2017). This number may further increase as the mapping of low transmission areas is finalized (World Health Organization, 2017). The Global Burden of Disease (GBD) Study 2017 estimated the disability-adjusted life years (DALYs) due to onchocerciasis as $1,340,000$ $(95 \%$ uncertainty interval (UI) $=639,000-2,370,000)$ in 2017 , representing a $7 \%$ decrease since 2005 , for which year the estimate was $1,442,000(95 \% \mathrm{UI}=835,000-2,289,000)(\mathrm{GBD}$ 2017 DALYs and HALE Collaborators, 2018). The most recent estimate of the GBD Study 2019 indicates a further decrease, with 1,230,000 (95\%UI = 765,000-1,820,000) DALYs due to onchocerciasis (GBD 2019 Cause and Risk Summaries, 2020). However, the GBD Study estimates only account for years lived with disability (YLD) and do not include years of life lost (YLL) due to premature death caused by infection, blindness or onchocerciasis- 
Revisiting the Strain Hypothesis in Onchocerciasis

associated epilepsy (Pion et al., 2002; Little et al., 2004b; Walker et al., 2012; Vinkeles Melchers et al., 2018).

\subsection{Onchocerca volvulus strains and Onchocerca-Simulium complexes}

In West Africa, blindness due to onchocerciasis has been reported to be more severe in savannah settings than in forest areas; in the former, in particular, it is mostly caused by sclerosing keratitis, but in both habitats blindness is positively correlated with the prevalence and intensity of O. volvulus microfilariae in the eye (Budden, 1963; Anderson et al., 1974). In highly endemic villages in Cameroon with equivalent prevalence of nodules located in the head (a predictor of ocular microfilariae and ophthalmological manifestations), the relative risk of having an eye lesion in patients with head nodules compared to those without them was nearly three times as high in the savannah as in the forest (Fuglsang et al., 1976).

These observations, together with vector cross-experimental infection studies reporting that forest blackflies had lower competence for savannah parasites and vice versa (Duke, 1966; Duke, 1967; Duke, 1970; Duke et al., 1966; Duke et al., 1967; Lewis and Duke, 1966; Philippon, 1977), led to the notion of parasite strain differences and to the concept of locally adapted Onchocerca-Simulium complexes (see Basáñez et al., 2009 for a review). Further evidence in favour of the 'strain hypothesis' was provided by injections of O. volvulus microfilariae from both savannah- and forest-based patients into eyes of rabbits and subsequent examinations of their effects on ocular pathology (Duke and Anderson, 1972; Duke and Garner, 1973; Garner et al., 1973). In addition, savannah village-level data showed a positive relationship between intensity of transmission, measured by the annual transmission potential (ATP, the number of infective, L3, larvae to which a person living in the village would be exposed during a year) and the prevalence of ocular lesions and blindness in the village (Duke et al., 1975) which, although also present in rainforest 
communities (Duke et al., 1972), did not reach the high levels of blindness prevalence reported for savannah settings. A positive linear relationship between intensity of transmission, measured by numbers of L3 infective larvae per 1,000 parous $S$. yahense flies, and blindness has also been more recently documented with forest data in Liberia (Cheke and Garms, 2013).

Attempts using a variety of techniques have been made to find biomarkers that differ according to $O$. volvulus strain. Flockhart et al. (1986) compared samples of $O$. volvulus from forest foci in Côte d'Ivoire and Liberia with samples from savannah foci in Burkina Faso and Sudan using isoenzyme analyses. Of seven enzymes examined, three were invariant and four were polymorphic enzymes, but only three of these showed sufficient variation for inclusion in an analysis of variance of their genotype frequencies, and only one (malate dehydrogenase) showed a substantial percentage difference $(28.1 \%)$ between the countries. Also, calculations of genetic distances based on allele frequencies revealed that the differences between countries were minimal and it was concluded that "all genetic distances were within the range expected for geographical populations of the same species". Erttmann et al. (1987) identified a DNA sequence (pFS-1) that hybridised to four samples of forest $O$. volvulus from Liberia and to a sample from the forest/savannah transition zone in Togo but not to two savannah samples from Mali and a sample from Brazil. Subsequently, Erttmann et al. (1990) reported finding a sequence, termed pSS-1BT which appeared to be specific for savannah O. volvulus. These forest and savannah sequences were from a variable tandemly repeated DNA sequence family of $\sim 150$ base pairs (bp) designated O-150. A PCR-based test was developed for strain identification (Meredith et al., 1991), which combined the amplification of the O-150 repeat using species-specific primers and hybridisation with the two strain-specific probes to identify savannah and forest strains. The species-specific probe pOVS134 overlapped the primer sites and the authors redesigned a new species-specific probe, OVS, to identify 
O. volvulus species. This test has been widely used (e.g. Toé et al., 1994, 1997; Zimmermann et al., 1992, 1994; Ogunrinade et al., 1999) without confirming unequivocal habitat- or vector-related distinctions. Subsequently, Merriweather and Unnasch (1996) developed another probe (C1 A1-2) for more accurate means of distinguishing O. volvulus from the cattle parasite $O$. ochengi. Onchocerca ochengi, which is also transmitted by $S$. damnosum s.l., is the closest relative of $O$. volvulus, having probably switched from cattle to humans less than 5,000 years ago (Morales-Hojas et al., 2006).

Analyses of nuclear DNA, mitochondrial DNA and genes coding for antigenic proteins have suggested that populations of $O$. volvulus can have a mix of habitat-related markers and that they can and do interbreed (Keddie et al., 1999; Choi et al., 2016). This genetic mixing may be readily maintained by the migrations of both vectors (Garms et al., 1979; Cheke and Garms, 1983; Baker et al., 1990) and humans, including traditional transhumance and pastoralism from the Sahel to forests and back (FAO-CIRAD, 2012) and recent economic migration (Zachariah and Condé, 1981), with implications for recrudescence of onchocerciasis (Koala et al., 2017). Nevertheless, recent analyses based on mitochondrial DNA revealed that geographically distinct populations have genetic structure consistent with vector migration patterns (Crawford et al., 2019; Hedtke et al., 2020), knowledge of which could be useful for defining transmission zones (geographical areas where transmission of O. volvulus occurs by locally-breeding vectors and which can be regarded as a natural ecological and epidemiological unit for interventions).

Endosymbiont Wolbachia pipientis bacteria occur in both the parasite and the vector. Lack of Wolbachia seems to be the ancestral condition in O. volvulus (Bandi et al., 2001) and, as Wolbachia are implicated in the pathogenesis of onchocerciasis (Saint André et al., 2002; Pearlman and Gillette-Ferguson, 2007; Tamarozzi et al., 2011), variation in these 
within the parasite (Choi et al., 2016) could account for differences in disease outcomes. Similar variation in Wolbachia within the vectors is yet to be studied in detail but Wolbachia do occur in S. squamosum E (Crainey et al., 2010, 2017) and S. yahense (J.L. Crainey, pers. comm.) and so are also likely to have epidemiological significance. Genetic variation within and between the vectors in West Africa is extensive (Vajime and Dunbar, 1975; Adler et al., 2010) and is well known to have important consequences for the transmission of onchocerciasis (Cheke and Garms, 2013).

Adherence to the forest-savannah strain hypothesis led to the initial vector control operations undertaken by the OCP being restricted to savannah foci (World Health Organization, 1987). After the initiation of the OCP (see O'Hanlon et al., 2016 for a description of the OCP's initial phases and further extensions), a series of papers compared the village-level prevalence of onchocerciasis-associated ocular lesions as a function of the intensity of skin infection by microfilariae. The latter was measured as the community microfilarial load (CMFL, defined in Remme et al., 1986 as the geometric mean number of microfilariae per skin snip (mf/snip) in those aged $\geq 20$ years) between savannah West African foci (where the parasite was transmitted by S. damnosum sensu stricto (s.str.)/S. sirbanum, Remme et al., 1989) and forest foci with different prevailing vector species (e.g. S. yahense in south-western Côte d'Ivoire, Dadzie et al., 1989; S. sanctipauli in southern Côte d'Ivoire, Dadzie et al., 1990; S. soubrense B (= S. leonense) in southern Sierra Leone, Dadzie et al., 1992). After adjusting for differences in CMFL (typically higher in savannah than in forest communities), these studies concluded that for a given CMFL, the prevalence of ocular lesions and the 'blinding potential' of the parasite in forest settings were lower than those in the savannah (with the possible exception of the degraded forest in southern Sierra Leone, where CMFL values were also high). This morbidity paradigm was adopted by Coffeng et al. (2013) to estimate the DALYs due to onchocerciasis in the APOC 
area and the health impact of this programme in terms of DALYs averted from its inception in 1995 to its closure in 2015 .

Whilst the evidence for different parasite strains in African savannah and forest initially relied mostly on epidemiological data, clear differences were also documented in the simuliid vectors. Not only did the $S$. damnosum complex prove to comprise a variety of cytospecies and cytoforms (Vajime and Dunbar, 1975; Adler et al., 2010) which had different habitat preferences, but there were also differences in their vectorial abilities and their infection intensities of larval O. volvulus stages. Simulium damnosum s.str. and S. sirbanum, species typically found in savannah regions, transmit fewer infective larvae per infective fly than do forest-dwelling species such as S. sanctipauli (Cheke and Garms, 2013). The latter species also have much higher variances of numbers of developing stages of Onchocerca larvae per fly, and so the (overdispersed) frequency distributions of numbers of parasites per fly have longer tails. (Overdispersion is defined in comparison to the Poisson distribution, in which the variance is equal to the mean and, therefore, the variance over mean ratio $=1$; an overdispersed distribution is characterised by a variance over mean ratio $>>1$.) Although these differences may have been ascribed to the parasite strain that each type of vector ingested, more fundamental population biology processes may be at play. For instance, negative density dependence acting on ingested microfilariae has been reported to limit the output of L3 per fly in the savannah species of the S. damnosum complex (Philippon and Bain, 1972; Basáñez et al., 1995), whereas density independence (leading to a linear relationship between the number of larvae successfully establishing within the vector and microfilarial load) has been described in forest species (Demanou et al., 2003; SoumbeyAlley et al., 2004); reviewed in Basáñez et al. (2009). At a forest-savannah mosaic site in southern Togo, Garms and Cheke (1985) noticed that populations of the Beffa form of S. soubrense, harboured the "forest" pattern of larval distributions but were occurring 
sympatrically with S. damnosum s.str./S. sirbanum harbouring "savannah" distributions. Given that the flies were biting the same population of people, it was unlikely that two parasite strains were involved, but rather that there were intrinsic differences between the two vector taxa regarding the specificities of vector-parasite interactions which determine how they respond to ingested microfilariae. Similarly, there have been reports of a lack of consistency with the blinding-non-blinding strain divide with observations of high levels of onchocerciasis-associated blindness in forest-savannah mosaic areas of Nigeria (Umeh et al., 1996) and Cameroon (Pion et al., 2002).

\subsection{Revisiting the forest-savannah strain hypothesis and review aims}

The simple forest-savannah strain hypothesis was questioned by Cheke and Garms (2013) on the basis of extensive entomological data in relation to blindness prevalence in West Africa. They found that high blindness prevalences in forested parts of Liberia were associated with transmission by forest vectors but that the proportions of first and second stage (L1/L2) Onchocerca larvae that succeeded in becoming third stage (L3) infective larvae did not differ between different vectors species (Table 6 of Cheke and Garms, 2013), with the maximum values of such proportions being essentially the same as those of $S$. damnosum s.str./S. sirbanum. This suggests that what differs between vector species is the probability of microfilariae successfully establishing within the fly's thorax; once established-in a competent vector - the proportion developing does not differ greatly (Basáñez et al., 1995). Novel research assessing micro-computerised tomography (micro-CT) scans of the peritrophic matrix in both forest and savannah blackflies preserved soon after feeding did not support the hypothesis that forest vectors have thinner peritrophic matrices (Philippon, 1977), which would permit a greater proportion of ingested microfilariae to reach the haemocoele of the flies and ultimately lead to more Onchocerca L3 larvae developing than in savannah 
vectors (Hall et al., 2020). Cheke and Garms (2013) concluded that a complex of factors may be at play, perhaps including the involvement of Wolbachia endosymbionts in the flies and/or the worms.

In a preliminary study of the data re-analysed here-village-level estimates of blindness prevalence, microfilarial prevalence, and transmission intensity from 16 WestCentral Africa studies-Little et al. (2003) concluded that there was no statistically significant difference between the prevalence of blindness in savannah and forest settings. Here we re-examine these epidemiological data and conclude that the evidence for the existence of two distinct savannah and forest $O$. volvulus strains associated, respectively, with more or less severe ocular onchocerciasis, is weak. In particular, we find that prevalence of blindness estimates in the savannah are not significantly different from those in the forest and that in both forest and savannah, blindness prevalence varies with transmission rates. We have largely restricted our analysis to data from West Africa, while including Cameroon from West Central Africa, because the original conception of the strain hypothesis was based on data from this zone.

\section{METHODS}

\subsection{Inclusion criteria for studies in West Africa}

We collated data from studies that were suitable to be included in the analysis on the basis of the following criteria: (a) studies conducted within the geographical area of West Africa but including Cameroon and the island of Bioko, which is in the Gulf of Guinea and is part of Equatorial Guinea; (b) studies conducted before (at baseline) or in the initial phases of the implementation of a control programme, as interventions based on the use of larvicides for vector control (by the OCP) or on mass microfilaricidal treatment (with ivermectin) could 
have distorted the results (a maximum of two years from the inception of interventions was allowed for vector control following O'Hanlon et al. (2016); only pre-intervention data at initial endemicity and transmission intensity were used in case of ivermectin distribution); (c) studies including the prevalence of bilateral blindness, the prevalence of skin microfilariae and/or the intensity of transmission (measured by the ATP), and (d) studies including vector identification or conducted in areas where entomological data were also available.

Sixteen publications with data on onchocerciasis from 93 communities in West Africa reporting prevalence of blindness with either associated ATPs or prevalence of microfilaridermia (\% $\%$ f) were collated (Table 2) and assigned to a habitat (savannah, forestsavannah mosaic or forest). The earliest study was conducted in 1968 and the latest in 1998. Some publications did not include any data on microfilarial density $(\mathrm{mf} / \mathrm{snip}$ or $\mathrm{mf} / \mathrm{mg})$ in the overall population, while others quoted such data or reported CMFLs instead, hence possible effects of microfilarial intensities were not investigated. Only data for which the numbers of patients examined were given in a publication were included. Bilateral blindness was used as the outcome variable. Blindness was defined as either a visual acuity of $<3 / 60$ or the inability to count fingers at a distance of one metre (Little et al., 2004a). As the data came from many different studies, it was necessary to standardise them to make the measures comparable, so far as possible.

\section{[Insert Table 2 about here]}

\subsection{Standardization of prevalence by age and sex}

The community prevalence of skin microfilariae and the blindness prevalence by both age and sex required standardisation. This is important as both measures are known to increase with cumulative exposure (and therefore age), and to differ significantly between the sexes 
(see Hamley et al., 2019 for relationships between age- and sex-standardised microfilarial prevalence and annual biting rate (ABR) in savannah settings before intervention fitted using the stochastic EPIONCHO-IBM transmission model). Standardising adjusts for different ageor sex-compositions of different villages or study samples. Some of the studies included results that had already been standardised for both age and sex, by either the direct or indirect methods (Kirkwood and Sterne, 2003), while others had either only been standardised for one or the other or neither. In these cases, the data required standardisation using the following process. We first identified a reference population, broken down into age and sex categories; this could be either the census population of the region or country given by the author (indirect standardisation) or it could be estimated by pooling age and sex data from all of the villages in the study (direct standardisation). We then multiplied the prevalence (of microfilaridermia or of blindness) in each (age, sex) category within the study population by the proportion of people in each corresponding category in the standard population. This gave the weighted (mean) prevalence of infection and blindness within each category. Finally, we calculated the age- and sex-standardised prevalence as the sum of these weighted means (Kirkwood and Sterne, 2003).

\subsection{Standardization of incubation period and media for skin snips}

As the studies analysed covered a span of several decades the methods used varied, particularly in the estimation of microfilarial prevalence. Prevalence of microfilaridermia was estimated by taking small $\sim 1-2 \mathrm{mg}$ skin snips from each individual, with usually at least two snips taken from the same or different regions of the body. Originally this was done using a pin and a razor blade and latterly superseded by a Holth-type corneo-scleral biopsy instrument (Moreau et al., 1978). These skin snip samples were incubated for a period to allow the microfilariae to emerge from the biopsy. It was during this step that the studies 
varied most, with the snips incubated from 10 minutes to 24 hours. In several studies the skin snips were also teased to stimulate emergence of microfilariae. All three of these factors needed to be standardised in order to make the samples comparable as the number of positive samples (prevalence) increases with incubation time and varies with incubation medium. Collins et al. (1980) calculated the mean percent of skin snips that became positive after different intervals as a percentage of those that were positive at 24 hours. The percentages according to different intervals (Table 3) were used to adjust prevalence estimates, standardizing to a 24-hour incubation. For those studies in which the samples were teased (and then incubated for 15 minutes) it was assumed, following Demanou et al. (2003), that the number of microfilariae that emerged was approximately half that which would have emerged if incubated for 24 hours without teasing. No adjustments were made for the part of the body that was snipped as these were usually found to be similar (Demanou et al., 2003; but see Bottomley et al., 2016).

\section{[Insert Table 3 about here]}

\subsection{Cytotaxonomic and habitat classifications}

Cytotaxonomic data on the vectors were presented in some of the identified studies. Where such data were not presented, and for samples taken within the area covered by the OCP, the simuliid cytospecies present in the study sites were taken from the maps in Boayke et al. (1998), and the data in Cheke et al. (1987) and Cheke et al. (1992). For other areas not in the OCP such as Liberia, data were taken from Vajime and Dunbar (1975).

The following simuliid species were found in the studies analysed: Simulium damnosum s.str., S. sirbanum, S. squamosum, S. soubrense, S. leonense, Beffa form of S. soubrense, S. sanctipauli, S. yahense, S. mengense. 
Decisions on habitat classifications were based on information in the publications, but when there was doubt about how the habitat terms had been used or if no information was provided, the habitat was defined according to the vegetation map of White (1983).

\subsection{Statistical analyses}

Analysis using a binomial generalised linear model (GLM) (with logit link) showed evidence of severe overdispersion (extra-binomial variation) in the data (residual deviance of 6,820 in 86 degrees of freedom). Correcting this overdispersion by means of a quasibinomial GLM was rejected on the basis of model diagnostic plots, but an analysis of variance (ANOVA) with angular transformation of prevalence (percentage) data had acceptable model diagnostics. The transformation (asin(sqrt(percentage/100))) was very similar to the logit link in the GLM. The effect of the arcsine transformation is similar to the logit, in that it expands the ends of the distribution, but not to the extent that the logit does (Holland, 2017). Charts based on ANOVA models with angular-transformed data show means and standard errors detransformed from model coefficients, resulting in asymmetrical error bars. In order to take sample sizes into account, the value of the denominator of the authors' percent blindness calculations was used if reported; otherwise, the total sample size for the whole study was substituted. The analyses thus consist of weighted linear models using angular-transformed percentage data. All analyses were conducted using R (R Core Team, 2016). An explanation of the procedures involved and the associated data file and R-codes are provided in the Supplementary Material available in the online version of this article. 


\section{RESULTS}

\subsection{All causes of blindness}

Using the raw data, there was no statistically significant difference between prevalence of blindness according to habitat (one-way ANOVA, $\mathrm{P}=0.38$; Figure $2 \mathrm{~A}$ ). With the raw data weighted by sample size, there was also no statistically significant effect of habitat on the prevalence of blindness (one-way ANOVA, $\mathrm{P}=0.68$; Figure $2 \mathrm{~B}$ ). Similarly, but with a linear model using angular-transformed percentage data on unweighted data, there was also no significant effect of habitat on the prevalence of blindness (one-way ANOVA, $\mathrm{P}=0.53$; Figure 2C). This was also the case for a linear model using angular-transformed percentage data weighted by sample size (one-way ANOVA, $\mathrm{P}=0.40$; Figure 2D).

\section{[Insert Figure 2 about here]}

\subsection{Blindness due to onchocerciasis}

The results above were based on 93 records using data on blindness which included some publications that did not distinguish between blindness due to onchocerciasis and blindness due to other causes. However, amongst the publications, data on 52 communities were specified as being based on onchocerciasis-associated blindness only. When these data were analysed using the weighted linear model method, there was again no evidence of any statistical difference in blindness prevalence according to habitat (one-way ANOVA, $\mathrm{P}=$ 0.51 ; Figure 3).

\section{[Insert Figure 3 about here]}




\subsection{Bilateral blindness}

There are 11 data points for which there was no information to establish whether these data referred to bilateral blindness. These data are from De Sole et al. (1992), who reported data on blindness without specifying if they were referring to bilateral blindness or not. Therefore, firstly the data were analysed assuming that blindness denoted bilateral blindness, but to check the robustness of the results to this assumption, we conducted a further analysis excluding the 11 ambiguous data points (denoted by an asterisk in Table 2). This analysis again indicated no statistically significant difference in blindness prevalence according to habitat $(\mathrm{P}=0.17)$.

\subsection{Forest blindness}

The forest data are more heterogeneous than the savannah data, as illustrated by Figure 4, in which the forest data are separated according to country. Country was significantly associated with forest blindness prevalence (ANOVA, $\mathrm{P}<0.0001$ ). Indeed, the prevalence of blindness in Cameroon is significantly greater than that in Côte d'Ivoire $(\mathrm{P}=0.008)$ and Liberia (Tukey multiple comparisons of means, $\mathrm{P}=0.006$ ). This result may reflect differences in the vectors present in each country and/or their transmission abilities in relation to local infection intensities, or other hitherto unidentified factors associated with ocular pathology. Whereas the vectors in the savannah habitats are predominantly S. damnosum s.str. and S. sirbanum, those for the forest habitats are variable (Table 2). In Cameroon, the forest vectors are S. squamosum (forms A, B, C \& D; see Mustapha et al., 2004) and S. mengense; in Liberia they are S. soubrense (sensu Post 1986, formerly S. sanctipauli s.str., see Kashan and Garms, 1987) and S. yahense; in Côte d'Ivoire they are S. sanctipauli and S. yahense, with the latter present in a few sites only, and in Bioko the vector was the unique endemic Bioko form of S. yahense (Post et al., 2003) before it was eliminated (Traoré et al., 2009). 


\section{[Insert Figure 4 about here]}

\subsection{Transmission intensity and microfilarial prevalence}

In order to examine whether there were any significant effects of transmission intensity rates as measured by ATPs, or prevalence of infection in the community measured by standardised percentages of the population with skin microfilariae (\%mf), one-way ANOVA analyses were conducted on the weighted data for all blindness (i.e. not just those specified as due to onchocerciasis only) but excluding data from forest-savannah mosaic settings due to their paucity with associated ATP or \% mf data. Given that the blindness prevalence estimates for the forest settings in Côte d'Ivoire were significantly lower than those of other countries' forest habitats (Figure 4), the forest data were analysed with and without the Côte d'Ivoire data and compared with those for the savannah in Figure 5. The relationship between ATP (annual transmission potential) and angular-transformed percent blindness (blindness prevalence) for all forest data analysed together was not statistically significant (Figure 5A; P $=0.98$ ) but for forest data without those from southern Côte d'Ivoire, the relationship was positive and statistically significant (Figure 5B; $\mathrm{P}<0.007$ ); furthermore, its slope was not significantly different from that for the savannah data plotted in Figure 5C (t-test for difference between slopes, $\mathrm{P}=0.24$ ), which also have a positive and significant relationship between ATP and blindness prevalence $(\mathrm{P}=0.0003)$.

\section{[Insert Figure 5 about here]}

A similar analysis of the data on microfilarial prevalence and angular-transformed blindness prevalence revealed a statistically significant and positive relationship for the savannah data (Figure 6A; $\mathrm{P}<0.0001$ ) but not for the forest data with (Figure 6B; $\mathrm{P}=0.49$ ) or without (Figure $6 \mathrm{C} ; \mathrm{P}=0.77$ ) the southern Côte d'Ivoire data. 


\section{[Insert Figure 6 about here]}

\section{DISCUSSION}

\subsection{Transmission intensity and locally-adapted Onchocerca-Simulium populations}

The results, based only on blindness prevalence, do not support the existence of a distinct blinding (savannah) strain of $O$. volvulus in dichotomous contrast with a non-blinding (forest) strain. No statistically significant differences were found between the prevalence of blindness reported from forest, forest-savannah mosaic or savannah habitats. Furthermore, the wellknown relationship between transmission rates (ATP, the number of L3/person/year) and blindness prevalence in savannah habitats also holds for forested areas if the data for the forest region of southern Côte d'Ivoire (Dadzie et al., 1990), where blindness prevalence estimates were significantly lower than in other West African countries' forest foci, are excluded. When the Côte d'Ivoire data are excluded, there is also no difference between the relationships between ATP and blindness prevalence for different habitats (but see Duke et al., 1972 and Duke et al., 1975 for relationships between ATP and prevalence of ocular lesions including blindness in southern Cameroon for forest and savannah, respectively).

The forest zone of southern Côte d'Ivoire was known to have low levels of CMFL, skin lesions and onchocerciasis-associated blindness, with sclerosing keratitis absent. This was attributed to parasite strain differences (Dadzie et al., 1990). However, the main vectors there were unique forms (the Comoé and Sassandra forms) of S. sanctipauli (Boakye et al., 1999). Therefore, we suggest that, rather than parasite strain differences accounting for the low blindness levels in the forest sites studied in Côte d'Ivoire, these may be due to the types of vector present, despite the high ATPs recorded in some Côte d'Ivoire forest foci (Table 1). 
Perhaps a high ATP, based on dissections of flies, does not always correspond to high transmission to humans. This may be the case if the flies do not feed for long enough to inoculate all of their larvae or if some of the Onchocerca larvae found during the studies were not $O$. volvulus but zoophilic species such as $O$. ochengi, which is also transmitted by S. damnosum s.l. (Toé et al., 1994).

Toé et al. (1994) reported that ATPs may have been substantially overestimated particularly along the southern border of the OCP (where the forest sites of Côte d'Ivoire were located). Toé et al. (1997) also reported no differences in the numbers of L3 larvae of each 'strain' harboured by forest-dwelling blackfly species or in the numbers of forest and savannah larvae found in savannah-dwelling vector species. This supports our conjecture that rather than mere parasite strain differences, there are differences in parasite-host (vector and/or human) interactions and in competence for $O$. volvulus between vector species (which together with vector biting rates and their seasonal fluctuations translate into transmission potentials). Toé et al. (1997) concluded that classical vector-parasite transmission complexes did not play a part in the biology of onchocerciasis transmission in the area of the OCP.

\subsection{Onchocerca volvulus (and its Wolbachia endosymbiont) genetics}

Claims of molecular differences between forest and savannah $O$. volvulus in support of strain differences (Zimmerman et al., 1992; Zimmerman et al., 1994) were based on a variable tandemly repeated DNA sequence family of $\sim 150$ base pairs (bp) designated O- 150 . The variability of the 150-bp family was used to develop $O$. volvulus strain- and species-specific DNA probes (Meredith et al., 1991).

Subsequent studies, based on other (but still limited) markers such as mitochondrial restriction fragment length polymorphism (RFLP) profiles (Keddie et al., 1999), and nuclear 
internal transcribed spacer (ITS) rDNA sequences (Morales-Hojas et al., 2007), indicated a lack of population differentiation between savannah and forest isolates, in conflict with the two-strain hypothesis.

A recent study, aiming to overcome the restrictions imposed by analysis of limited genetic markers, undertook a comprehensive $O$. volvulus population genomics approach to investigate diversity in the parasite's nuclear, mitochondrial, and endosymbiotic Wolbachia genomes of 15 isolates from West Africa classified as 'savannah' or 'forest' according to O150 (Choi et al., 2016). Six isolates were from savannah sites in eastern Guinea, northwestern Côte d'Ivoire and northern Ghana, and nine from forest locations in Sierra Leone, Liberia, and southern Côte d'Ivoire, Ghana, and Benin. The three genomes indicated a certain degree of population structure, with the nuclear genome analysis providing phylogenetic signals consistent with gene flow and genetic admixture among discrete West African forest and savannah populations (Choi et al., 2016). In particular, there was evidence of unidirectional gene flow from the savannah to the forest. No discernible geographical pattern was detected in the distribution of West African mitochondrial DNA clades, in contrast to the bioclimatic (habitat in our analysis) separation observed in the nuclear genomes. These authors conclude that a simple dichotomy between forest and savannah 'strains' is an inadequate description of the parasite variations in West Africa, but remark that the results from the nuclear genome support the notion of geographically- and bioclimatically-structured populations (Choi et al., 2016). In agreement with the mitochondrial results, and in an attempt to evaluate the usefulness of the mitochondrial genome of $O$. volvulus for delineation of transmission zones, Crawford et al. (2019) reported a lack of (mitochondrial) population structure between forest samples from Côte d'Ivoire and savannah samples from Mali, in contrast to the $\mathrm{O}-150$ population differences between forest and savannah previously reported (Zimmerman et al., 1992). 
Higazi et al. (2005), using the same samples as in the Zimmerman et al. (1992) study (from Côte d'Ivoire, Ghana, Guinea, Senegal, Sierra Leone), reported that the median ratio of Wolbachia DNA to O. volvulus nuclear DNA was significantly greater in the 'severe' savannah parasite strain than in the 'mild' forest parasites despite wide variation among individual parasite samples from each location. More recently, Armoo et al. (2017), analysing samples representing savannah and forest habitats from Côte d'Ivoire, Ghana, Mali and Togo confirmed the observation of substantial variation in Wolbachia genome to O. volvulus nuclear genome copy number ratio within and between the samples analysed, but concluded that this variation was independent of habitat, in agreement with the Wolbachia genome results of Choi et al. (2016). The latter were unable to reveal any identifiable molecular or functional differentiating factor that could be related to pathogenesis; however, further highresolution polyomics profiling of Wolbachia symbionts, given their central inflammatory role, would be desirable.

\subsection{Age, sex and individual exposure patterns}

As the results presented here rely solely on blindness prevalence, habitat type, microfilarial prevalence and ATPs, we cannot be sure that there are no other habitat-related features of onchocerciasis that specialists in other disciplines (e.g. ophthalmologists, immunologists, population biologists, social scientists) rather than entomologists could point to. For instance, other factors determining the incidence and prevalence of ocular lesions and ultimately blindness in endemic communities include age- and sex-specific patterns of exposure to vector bites (Filipe et al., 2005) and parasite transmission that may prevail in different foci (Duke and Moore, 1968; Renz et al., 1987a; Bockarie and Davies, 1990) as well as the degree of inter-individual variation in exposure and susceptibility (Hamley et al., 2019). These factors cannot be understood by analysing transmission intensity rates measured by dissection 
of limited fly samples collected during a few weeks when landing on a few individuals (Renz, 1987; Renz and Wenk, 1987; Jacobi et al., 2010). There will be an interplay between processes regulating parasite load in humans, age- and sex-specific exposure patterns, and inter-individual host variation (Hamley et al., 2019; Hamley et al., 2020) that may well depend, in addition to human innate and behavioural or occupational factors, on habitat, vector species and transmission patterns. These may determine patterns of microfilarial prevalence and intensity, and ultimately prevalence of blindness in onchocerciasis-endemic communities along their distributional range.

\section{CONCLUSIONS AND RECOMMENDATIONS}

Differences in transmission patterns, vector biting habits, host susceptibility, and environmental aspects are among the factors that have been invoked to explain the seemingly higher prevalence of onchocerciasis-associated blindness in the savannah in comparison to that in forest areas of West Africa (Duke, 1981). A principal reason why the OCP decided not to treat vector breeding sites in the forest with larvicidal insecticides at the outset of the vector control programme was because of the assumption that the "blinding strain" was restricted to the savannah (Walsh et al., 1979). The results presented here show that this conclusion is not supported by a re-examination of the epidemiological evidence currently available. It seems possible that the earlier assumptions were biased by the unique situation in southern Côte d'Ivoire, which happened to be the area where much research had been conducted in forest foci during the period leading up to and at the beginning of the OCP (Phillippon, 1977; Quillévéré, 1979; Dadzie et al., 1989; Dadzie et al., 1990).

Intrinsic differences in the pathogenicity of savannah and forest parasites have been proposed to correlate with clinical ocular manifestations which are underpinned by 
population genetic structuring into neatly distinct savannah and forest strains (Zimmerman et al., 1992; Zimmerman et al., 1994). However, as we have shown here (and in Cheke and Garms, 2013), a re-appraisal of parasitological, entomological, and ophthalmological data, as well as the results from recent analyses of $O$. volvulus nuclear, mitochondrial and Wolbachia genomes (Choi et al., 2016; Armoo et al., 2017; Crawford et al., 2019) suggest a departure from the simple two-strain paradigm.

A re-evaluation of the two-strain hypothesis is advisable if the epidemiology of onchocerciasis is to be fully understood, better modelled (Basáñez et al., 2016), and its disease burden accurately estimated. This burden may have been underestimated as the initial clinico-epidemiological studies on ocular lesions conducted in forest foci of south and southwestern Côte d'Ivoire may have not been truly representative of forest ocular onchocerciasis. It also means that the public health impact and cost-effectiveness of reducing blindness due to onchocerciasis by past and ongoing (largely chemotherapeutic) control activities may have been underestimated (Coffeng et al., 2013). To address this is particularly important given the fillip of reaching revised onchocerciasis targets and milestones beyond 2020 (NTD Modelling Consortium Onchocerciasis Group, 2019), and achieving the health-related 2030 United Nations Sustainable Development Goals (World Health Organization, 2020).

\subsection{Implications for onchocerciasis control and elimination programmes}

The new WHO roadmap for NTDs (2021-2030) has proposed reaching elimination of transmission (EOT) as the target for onchocerciasis. This is in contrast to the goal of elimination as a public health problem (EPHP) proposed for other NTDs such as soiltransmitted helminthiases, schistosomiasis and lymphatic filariasis (World Health Organization, 2020). This means that the interventions that will be necessary to achieve EOT are 'agnostic' to the 'strain' hypothesis and no longer framed in terms of eliminating 
'blinding onchocerciasis'. Current intervention tools for achieving EOT largely consist of mass drug administration (MDA) of the endectocide ivermectin, mainly on an annual basis in Africa. Modelling studies have indicated that annual ivermectin MDA will be insufficient for EOT in highly endemic areas (those with high vector biting rates) and that alternative and complementary treatment strategies (ATS) will be essential (Verver et al., 2018; NTD Modelling Consortium Onchocerciasis Group, 2019). Some African countries have adopted biannual ivermectin MDA in some/most of their endemic foci (Katabarwa and Richards, 2014; Katabarwa et al., 2018; Turner et al., 2013), and in 2018, the Food \& Drug Administration (FDA) approved the use of moxidectin (another endectocide) for the treatment of human onchocerciasis in patients aged 12 years and older, based on evidence of its superior efficacy to that of ivermectin but comparable safety (see Milton et al., 2020 for a recent moxidectin review). Moxidectin may help to accelerate EOT in hypo- and mesoendemic foci and increase its feasibility in hyperendemic areas (Turner et al., 2015; Milton et al., 2020). However, the microfilaricidal properties of both ivermectin and moxidectin make them unsuitable for MDA delivery (treating of endemic populations without confirming individual infection status) in areas of onchocerciasis-loiasis coendemicity where the risks of severe adverse events (SAEs, in patients with high $L$. loa microfilaraemia) outweigh the benefits of onchocerciasis treatment (mainly in areas that are hypoendemic for onchocerciasis) (Cano et al., 2018). In these areas, TaNT protocols, i.e. test(for loiasis microfilaraemia levels)-and-not-treat (with ivermectin, if such levels exceed a dangerous threshold of $>30,000 \mathrm{mf} / \mathrm{ml}$ of blood, or $>20,000 \mathrm{mf} / \mathrm{ml}$ in some studies) have been successfully piloted in Cameroon (Kamgno et al., 2017). Other ATS, such as TTd (test(for onchocerciasis)-and-treat (with doxycycline)), also piloted in onchocerciasis-loiasis coendemic areas of Cameroon (Wanji et al., 2019) exploit the fact that (a 4-6 week course) of daily (100-200 mg) doxycycline treatment depletes the Wolbachia endosymbionts of 
O. volvulus (see section 1.2 Onchocerca volvulus strains and Onchocerca-Simulium complexes), exerting a macrofilaricidal and sterilising effect on adult worms (Tamarozzi et al., 2011; Walker et al., 2015), without affecting L. loa as the latter does not harbour Wolbachia (Taylor et al., 2005; Tamarozzi et al., 2011), circumventing the problem of SAEs, and providing a safe and efficacious curative treatment.

Large-scale and long-term application (weekly for at least 14 years) of aerial larvicidal insecticide treatment of vector breeding sites was effective for vector control in the OCP (Hougard et al., 2001). Although this modality of large-scale vector control is unlikely to be implemented elsewhere, aerial and supplementary ground-based larviciding led to the elimination of the Bioko form of S. yahense (Traoré et al., 2009). Therefore, the feasibility, efficacy, cost, environmental considerations (particularly in light of future sustainable management of forest ecosystems and biodiversity), and optimal localization, timing and duration of ground-based focal larviciding (Wanji et al., 2019), or of non-insecticidal community-directed approaches such as 'slash-and-clear' (Jacob et al., 2018) need to be further explored and their impact on vector biting rates modelled (Routledge et al., 2018; Smith et al., 2019).

\subsection{Future research avenues}

However agnostic to the onchocerciasis strain hypothesis interventions for control and elimination may need to be, epidemiological models of onchocerciasis transmission should certainly reflect the different features of the vector-parasite interaction observed in savannah and forest habitats, where different members of the S. damnosum s.l. complex prevail (Basáñez et al., 2009; Adler et al., 2010; Cheke and Garms, 2013). Given that the operation of density-dependent processes down-regulating parasite establishment in humans and blackfly vectors is a crucial determinant of the resilience of the host-parasite system to 
control interventions (Stolk et al., 2015; Basáñez et al., 2016; Walker et al., 2017; Verver et al., 2018; Hamley et al., 2019, 2020), it will be important to capture adequately such processes in savannah and forest environments. Savannah members of S. damnosum s.l. (i.e., S. damnosum s.s./S. sirbanum) exhibit limitation of the number of L3 larvae that develop within the flies as microfilarial load (and hence the number of microfilariae ingested by the flies) increases (Bain, 1971; Basañez et al., 1995; Soumbey-Alley et al., 2004), whereas forest and forest-savannah mosaic members of the complex (e.g. S. yahense; S. squamosum B; S. leonense) tend to exhibit proportionality (a more linear relationship between microfilarial counts and the number of larvae that successfully escape the peritrophic matrix of the flies and/or develop into L3 larvae (Cupp et al., 1986; Demanou et al., 2003; SoumbeyAlley et al., 2004), being able to harbour higher larval loads per fly (Basáñez et al., 2009; Adler et al., 2010; Cheke and Garms, 2013). Other differences between the operation of density-dependent processes in forest and savannah settings have been modelled regarding parasite establishment and fecundity rates within humans (Duerr et al., 2003, 2004). Yet, the two mathematical models that are used to inform decision-making in onchocerciasis, namely EPIONCHO and ONCHOSIM (NTD Modelling Consortium Onchocerciasis Group, 2019) are only parameterised for savannah settings (Basáñez et al., 2016). If (down-regulating) density-dependent processes were indeed weaker in forest locales, resilience to interventions (the ability of the parasite population to bounce back following treatment rounds or to resurge after stopping MDA) would also be weaker, increasing the feasibility of reaching EOT.

In addition to parasite population regulatory processes, age- and sex-specific exposure patterns, as well as the degree of heterogeneity in individual exposure may vary between forest and savannah settings. These factors interact with density dependence to determine the magnitude of onchocerciasis elimination thresholds (Hamley et al., 2020). Models indicate that the stronger the degree of heterogeneity in inter-individual exposure, the more difficult 
EOT becomes (Winnen et al., 2002; Hamley et al., 2019). Interestingly, Budden (1963) suggested that exposure to blackfly bites was much more clustered in the savannah than in the forest (due to differences in transmission seasonality, distribution of breeding sites, and patterns of human settlement and occupation), and that this difference may help to explain epidemiological patterns of microfilarial prevalence, intensity, and ocular manifestations. To illustrate this, Budden (1963) reported than in forest settings of southern Cameroon, skin microfilarial infection was widespread (nearly all villages were affected) and prevalence in adults reached c. $100 \%$, yet intensity of infection in the skin and eyes was relatively low. By contrast, in savannah settings, highly exposed individuals would develop high intensities of cutaneous and ocular infection, and resulting ocular lesions. In support of these observations, Gbakima and Barbe (1992) reported that in five hyperendemic villages of Sierra Leone (overall microfilarial prevalence of 62\%), the intensity of infection was low and microfilarial invasion of the eye was also low, with corresponding low prevalence of anterior chamber lesions (although that of posterior chamber lesions was relatively high, mainly comprising optic atrophy and choroidoretinitis), with an overall prevalence of blindness of $1.6 \%$.

We, therefore, recommend that transmission models be parameterised and fitted to epidemiological and entomological forest onchocerciasis data (e.g. Duke et al., 1972; Barbiero and Trpis, 1984a, 1984b; Bockarie and Davies, 1990; Bockarie et al., 1990; Fryauff and Trpis, 1987; Trpis, 2006; Wanji et al., 2015) as has been done for savannah data (Hamley et al., 2019), and that differences in age- and sex-specific profiles of exposure and infection across endemic settings be better understood. An approach that may be suitable for estimating exposure to blackfly bites is the development of anti-saliva antibody assays, such as used in sandflies and leishmaniasis (Kostalova et al., 2015; Quinnell et al., 2018). Such assays, initially based on titres of antibody responses to crude blackfly salivary antigens, could be used in serological population studies across all age and sex groups and may provide useful 
data for estimating age- and sex-dependent exposure as well as heterogeneity in individuallevel exposure to blackfly bites. These assays may also be combined with those used for serological monitoring of exposure to O. volvulus infection (e.g. Ov16) to provide data that would permit interrogation of modelling assumptions regarding exposure and parasite establishment in forest, forest-savannah mosaic, and savannah settings to better inform onchocerciasis control and elimination efforts across Africa.

\section{Acknowledgements}

RAC and SY are grateful to the University of Greenwich for providing facilities and research funds. MGB acknowledges joint centre funding (grant No. MR/R015600/1) by the UK Medical Research Council (MRC) and the UK Department for International Development (DFID) under the MRC/DFID Concordat agreement which is also part of the European and Developing Countries Clinical Trials Partnership (EDCTP2) programme supported by the European Union. We thank Dr R. Morales-Hojas for comments on the molecular epidemiology aspects of the study.

\section{List of Abbreviations}

ABR, annual biting rate; ANOVA, Analysis of variance; APOC, African Programme for Onchocerciasis Control; ATS, Alternative treatment strategies; asin(sqrt)), arcsine transformation, also called the arcsine square root transformation, or angular transformation, ATP, annual transmission potential; bp, base pairs; CMFL, community microfilarial load; CT, computerised tomography; DALY, disability-adjusted life years; DNA, deoxyribonucleic acid; EOT, elimination of transmission; EPHP, elimination as a public health problem; GBD, Global Burden of Disease; GLM, generalised linear model; ITS, internal transcribed spacer; $\mathbf{m f} / \mathbf{m g}$, microfilariae (of $O$. volvulus) per milligram of skin; 
$\mathbf{m f} / \mathbf{m l}$, microfilariae (of Loa loa) per millilitre of blood; mf/snip, microfilariae (of O. volvulus) per skin snip; mg, milligram; L1, sausage-stage larva; L2, pre-infective larva; L3, infective larva; MDA, mass drug administration; NTD, neglected tropical disease; OCP, Onchocerciasis Control Programme in West Africa; rDNA, ribosomal DNA; RFLP, restriction fragment length polymorphism; SAE, severe adverse events (severe drug reactions); S.E., standard error; s.l., sensu lato; s.str., sensu stricto; TaNT, test (for loiasis microfilaraemia levels) and not treat (with ivermectin); TTd, test (for onchocerciasis) and treat (with doxycycline); UI, uncertainty interval; WHO, World Health Organization; YLD, years lived with disability; YLL, years of life lost; \% $\mathbf{m f}$, prevalence of (O. volvulus) microfilaridermia.

\section{REFERENCES}

Abiose, A., Murdoch, I., Babalola, O., Cousens, S., Liman, I., Onyema, J., Evans, J., Gregory, W., Jones, B., 1994. Distribution and aetiology of blindness and visual impairment in mesoendemic onchocercal communities, Kaduna State, Nigeria. Kaduna Collaboration for Research on Onchocerciasis. Br. J. Ophthalmol. 78 (1), 8-13.

Adler, P.H., Cheke, R.A., Post, R.J., 2010. Evolution, epidemiology, and population genetics of black flies (Diptera: Simuliidae). Infect. Genet. Evol. 10 (7), 846-865.

African Programme for Onchocerciasis Control, 2005. Final communiqué of the 11th session of the Joint Action Forum (JAF) of APOC, Paris, France, 6-9 December 2005. Ouagadougou (Burkina Faso): APOC. Available: https://www.who.int/apoc/about/structure/jaf/jaf11_final_communique.pdf. Accessed: 8 December 2020.

Albiez, E.J., Ganley, J.P., Büttner, D.W., 1981. Ocular onchocerciasis in a hyperendemic village in the rain forest of Liberia. Tropenmed. Parasitol. 32 (1), 25-28.

Anderson, J., Fuglsang, H., Hamilton, P.J.S., Marshall TF de C., 1974. Studies on onchocerciasis in the United Cameroon Republic II. Comparison of onchocerciasis in the rain-forest and Sudan-savanna. Trans. R. Soc. Trop. Med. Hyg. 68 (3), 209-222. 
Armoo, S., Doyle, S.R., Osei-Atweneboana, M.Y., Grant, W.N., 2017. Significant heterogeneity in Wolbachia copy number within and between populations of Onchocerca volvulus. Parasit. Vectors. 10 (1), 188.

Baker, R.H., Guillet, P., Sékétéli, A., Poudiougo, P., Boakye, D., Wilson, M.D., Bissan, Y., 1990. Progress in controlling the reinvasion of windborne vectors into the western area of the Onchocerciasis Control Programme in West Africa. Philos. Trans. R Soc. Lond. B Biol. Sci. 328 (1251), 731-747.

Bain, O., 1971. [Transmission of filariasis. Limitation of passages of ingested microfilariae to the haemocoele of the vector; interpretation]. Ann. Parasitol. Hum. Comp. 46 (5), 613631 (in French).

Bandi, C., Trees, A.J., Brattig, N.W., 2001. Wolbachia in filarial nematodes: evolutionary aspects and implications for the pathogenesis and treatment of filarial diseases. Vet. Parasitol. 98 (1-3), 215-238.

Barbiero, V.K., Trpis, M., 1984a. The prevalence of onchocerciasis on selected divisions of the Firestone Rubber Plantation, Harbel, Liberia. Am. J. Trop. Med. Hyg. 33 (3), 403409.

Barbiero, V.K., Trpis, M., 1984b. Transmission of onchocerciasis by local black flies on the Firestone Rubber Plantation, Harbel, Liberia. Am. J. Trop. Med. Hyg. 33 (4), 586-594.

Basáñez, M.G., Churcher, T.S., Grillet, M.E., 2009. Onchocerca-Simulium interactions and the population and evolutionary biology of Onchocerca volvulus. Adv. Parasitol. 68, 263-313.

Basáñez, M.G., Pion, S.D.S., Churcher, T.S., Breitling, L.P., Little, M.P., Boussinesq, M., 2006. River blindness: a success story under threat? PLoS Med. 3 (9), e371.

Basáñez, M.G., Walker, M., Turner, H.C., Coffeng, L.E., de Vlas, S.J., Stolk, W.A., 2016, River Blindness: Mathematical models for control and elimination. Adv. Parasitol. 94, 247-341.

Basáñez, M.G., Remme, J.H.F., Alley, E.S., Bain, O., Shelley, A.J., Medley, G.F., Anderson R.M., 1995. Density-dependent processes in the transmission of human onchocerciasis: relationship between the numbers of microfilariae ingested and successful larval development in the simuliid vector. Parasitology. 110 (4), 409-427.

Boakye, D.A., Fiasorgbor, G.K., Bougsere, B.K., Naniogue, S., 1999. The cytotaxonomy of Simulium sanctipauli sensu stricto (Diptera: Simuliidae) in Ghana and the Côte d'Ivoire. Bull. Entomol. Res. 89 (1), 25-33. 
Boakye, D.A., Back, C., Fiasorgbor, G.K., Sib, A.P.P., Coulibaly, Y., 1998. Sibling species distributions of the Simulium damnosum complex in the West African Onchocerciasis Control Programme area during the decade 1984-93, following intensive larviciding since 1974. Med. Vet. Entomol. 12 (4), 345-358.

Bockarie, M.J., Davies, J.B., 1990. The transmission of onchocerciasis at a forest village in Sierra Leone. II. Man-fly contact, human activity and exposure to transmission. Ann. Trop. Med. Parasitol. 84 (6), 599-605.

Bockarie, M.J., Davies, J.B., Thomson, M.C., Morgan, H.G., 1990. The transmission of onchocerciasis at a forest village in Sierra Leone. I. Simulium damnosum s.l. biting densities and infection with Onchocerca volvulus at five representative sites. Ann. Trop. Med. Parasitol. 84 (6), 587-597.

Bottomley, C., Isham, V., Vivas-Martínez, S., Kuesel, A.C., Attah, S.K., Opoku, N.O., Lustigman, S., Walker, M., Basáñez, M.G., 2016. Modelling Neglected Tropical Diseases diagnostics: the sensitivity of skin snips for Onchocerca volvulus in near elimination and surveillance settings. Parasit. Vectors 9 (1), 343.

Boussinesq, M., 2006. Loiasis. Ann. Trop. Med. Parasitol. 100 (8), 715-731.

Bradley, J.E., Whitworth, J., Basáñez, M.G., 2005. Onchocerciasis. In: Cox, F.E.G., Wakelin, D., Gillespie, S.H., Despommier, D.D. (Eds.), Topley and Wilson's Microbiology and Microbial Infections (Parasitology Volume), 10th edition. Edward Arnold Publishers Ltd., London, UK, pp. 781-801.

Brattig, N.W., 2004. Pathogenesis and host responses in human onchocerciasis: impact of Onchocerca filariae and Wolbachia endobacteria. Microbes Infect. 6 (1), 113-128.

Budden, F.H., 1963. Comparative study of ocular onchocerciasis in savannah and rain forest. Trans. R. Soc. Trop. Med. Hyg. 57 (1), 64-70.

Buell, K.G., Whittaker, C., Chesnais, C.B., Jewell, P.D., Pion, S.D.S., Walker, M., Basáñez, M.G., Boussinesq, M., 2019. Atypical clinical manifestations of loiasis and their relevance for endemic populations. Open Forum Infect. Dis. 6 (11), ofz417.

Cano, J., Basáñez, M.G., O’Hanlon, S.J., Tekle, A.H., Wanji, S., Zouré, H.G., Rebollo, M.P., Pullan, R.L., 2018. Identifying co-endemic areas for major filarial infections in subSaharan Africa: seeking synergies and preventing severe adverse events during mass drug administration campaigns. Parasit. Vectors. 11 (1), 70.

Cheke, R.A., Garms, R., 1983. Reinfestations of the southeastern flank of the Onchocerciasis Control Programme area by windborne vectors. Philos. Trans. R Soc. Lond. B Biol. Sci. 302 (1111), 471-484. 
Cheke, R.A., Garms, R., 2013. Indices of onchocerciasis transmission by different members of the Simulium damnosum complex conflict with the paradigm of forest and savanna parasite strains. Acta Trop. 125 (1), 43-52.

Cheke, R.A., Garms, R., Ouedraogo, J., Somé, A., Sowah, S., 1987. The Beffa form of Simulium soubrense of the S. damnosum complex in Togo and Benin. Med. Vet. Entomol. 1 (1), 29-35.

Cheke, R.A., Sowah, S.A., Avissey, H.S.K., Fiasorgbor, G.K., Garms, R., 1992. Seasonal variation in onchocerciasis transmission by Simulium squamosum at perennial breeding sites in Togo. Trans. R. Soc. Trop. Med. Hyg. 86 (1), 67-71.

Cheke, R.A., Tirados, I., Mas, J., Geenan, P., Adjaru, J.M.M., Bouaha, J.L.A., Sima, A., Meyer, R.R.F., Wilson, M.D., 2006. Onchocerciasis transmission by the Bioko form of Simulium yahense Vajime \& Dunbar 1975 (Diptera: Simuliidae). Papers on the taxonomy, ecology and biology of black flies (Diptera: Simuliidae). Proceedings of the International Symposium on Simuliidae. Berlin 2004. Studia Dipterol. Suppl. 14, 2630.

Choi, Y.J., Tyagi, R., McNulty, S.N., Rosa, B.A., Ozersky, P., Martin, J., Hallsworth-Pepin, K., Unnasch, T.R., Norice, C.T., Nutman, T.B., Weil, G.J., Fischer, P.U., Mitreva, M. 2016. Genomic diversity in Onchocerca volvulus and its Wolbachia endosymbiont. Nat Microbiol. 2, 16207.

Coffeng, L.E., Stolk, W.A., Zouré, H.G.M., Veerman, J.L., Agblewonu, K.B., Murdoch, M.E., Noma, M., Fobi, G., Richardus, J.H., Bundy, D.A.P., Habbema, D., de Vlas S.J., Amazigo, U.V., 2013. African Programme for Onchocerciasis Control 1995-2015: model-estimated health impact and cost. PLoS Negl. Trop. Dis. 7 (1), e2032.

Colebunders, R., Siewe Fodjo, J.N., Hopkins, A., Hotterbeekx, A., Lakwo, T.L., Kalinga, A., Logora, M.Y., Basáñez, M.G., 2019. From river blindness to river epilepsy: Implications for onchocerciasis elimination programmes. PLoS Negl. Trop. Dis. 13 (7), e0007407.

Collins, R.C., Brandling-Bennett, D., Holliman, R.B., Campbell, C.C., Darsie, R.F., 1980. Parasitological diagnosis of onchocerciasis: comparisons of incubation media and incubation times for skin snips. Am. J. Trop. Med. Hyg. 29 (1), 35-41.

Crainey, J.L., Wilson, M.D., Post, R.J., 2010. Phylogenetically distinct Wolbachia gene and pseudogene sequences obtained from the African onchocerciasis vector Simulium squamosum. Int. J. Parasitol. 40 (5), 569-578. 
Crainey, J.L., Hurst, J., Lamberton, P.H.L., Cheke, R.A., Griffin, C., Wilson, M.D., De Araújo, C.P.M., Basáñez, M.G., Post, R.J., 2017. The genomic architecture of novel Simulium damnosum Wolbachia prophage sequence elements and implications for onchocerciasis epidemiology. Front. Microbiol. 8, 852.

Crawford, K.E., Hedtke, S.M., Doyle, S.R., Kuesel, A.C., Armoo, S., Osei-Atweneboana, M.Y., Grant, W.N., 2019. Utility of the Onchocerca volvulus mitochondrial genome for delineation of parasite transmission zones. bioRxiv. Available: http://dx.doi.org/10.1101/732446. Accessed: 8 December 2020.

Cupp, E.W., Bernardo, M.J., Kiszewski, A.E., Collins, R.C., Taylor, H.R., Aziz, M.A., Greene, B.M., 1986. The effects of ivermectin on transmission of Onchocerca volvulus. Science. 231 (4739), 740-742.

Dadzie, K.Y., De Sole, G., Remme, J., 1992. Ocular onchocerciasis and the intensity of infection in the community. IV. The degraded forest of Sierra Leone. Trop. Med. Parasitol. 43 (2): 75-79.

Dadzie, K.Y., Remme, J., Rolland, A., Thylefors, B., 1989. Ocular onchocerciasis and intensity of infection in the community. II. West African rainforest foci of the vector Simulium yahense. Trop. Med. Parasitol. 40 (3), 348-354.

Dadzie, K.Y., Remme, J., Baker, R.H.A., Rolland, A., Thylefors, B., 1990. Ocular onchocerciasis and intensity of infection in the community III. West African rainforest foci of the vector Simulium sanctipauli. Trop. Med. Parasitol. 41 (4), 376-382.

Demanou, M., Enyong, P., Pion, S.D.S., Basáñez, M.G., Boussinesq, M., 2003. Experimental studies on the transmission of Onchocerca volvulus by its vector in the Sanaga valley (Cameroon): Simulium squamosum B. Intake of microfilariae and their migration to the haemocoel of the vector. Ann. Trop. Med. Parasitol. 97 (4), 381-402.

De Sole, G., Accorsi, S., Cresveaux, H., Remme, J., Walsh, F., Hendrickx, J., 1992. Distribution and severity of onchocerciasis in southern Benin, Ghana and Togo. Acta Trop. 52 (2-3), 87-97.

Duke, B.O.L., 1966. Onchocerca-Simulium complexes. III. The survival of Simulium damnosum after high intakes of microfilariae of incompatible strains of Onchocerca volvulus, and the survival of the parasites in the fly. Ann. Trop. Med. Parasitol. 60 (4), 495-500.

Duke, B.O.L., 1967. Onchocerca-Simulium complexes. IV. Transmission of a variant of the forest strain of Onchocerca volvulus. Ann. Trop. Med. Parasitol. 61 (3), 326-331. 
Duke, B.O.L., 1970. Onchocerca-Simulium complexes. VI. Experimental studies on the transmission of Venezuelan and West African strains of Onchocerca volvulus by Simulium metallicum and S. exiguum in Venezuela. Ann. Trop. Med. Parasitol. 64 (4), $421-431$.

Duke, B.O.L., 1981. Geographical aspects of onchocerciasis. Ann. Soc. Belg. Med. Trop. 61 (2), 179-186.

Duke, B.O.L., 1993. The population dynamics of Onchocerca volvulus in the human host. Trop. Med. Parasitol. 44 (2), 61-68.

Duke, B.O.L., Anderson, J., 1972. A comparison of the lesions produced in the cornea of the rabbit eye by microfilariae of the forest and Sudan-savanna strains of Onchocerca volvulus from Cameroon. I. The clinical picture. Z. Tropenmed. Parasitol. 23 (4), 354368.

Duke, B.O.L., Garner, A., 1973. Fundus lesions in the rabbit eye following inoculation of Onchocerca volvulus microfilariae into the posterior segment. I. The clinical picture. Tropenmed. Parasitol. 27 (1), 3-17.

Duke, B.O.L., Moore, P.J., 1968. The contributions of different age groups to the transmission of onchocerciasis in a Cameroon forest village. Trans. R. Soc. Trop. Med. Hyg. 62 (1), 22-28.

Duke, B.O.L., Anderson, J., Fuglsang, H., 1975. The Onchocerca volvulus transmission potentials and associated patterns of onchocerciasis at four Cameroon Sudan-savanna villages. Tropenmed. Parasitol. 26 (2), 143-154.

Duke, B.O.L., Lewis, D.J., Moore, P.J., 1966. Onchocerca-Simulium complexes. I. Transmission of forest and Sudan-savanna strains of Onchocerca volvulus, from Cameroon, by Simulium damnosum from various West African bioclimatic zones. Ann. Trop. Med. Parasitol. 60 (3), 318-336.

Duke, B.O.L., Moore, P.J., Anderson, J., 1972. Studies on factors influencing the transmission of onchocerciasis. VII. A comparison of the Onchocerca volvulus transmission potentials of Simulium damnosum populations in four Cameroon rainforest villages and the pattern of onchocerciasis associated therewith. Ann. Trop. Med. Parasitol. 66 (2), 219-234.

Duke, B.O.L., Moore, P.J., De León, J.R., 1967. Onchocerca-Simulium complexes. V. The intake and subsequent fate of microfilariae of a Guatemalan strain of Onchocerca volvulus in forest and Sudan-savanna forms of West African Simulium damnosum. Ann. Trop. Med. Parasitol.61 (3), 332-337. 
Duerr, H.P., Dietz, K., Schulz-Key, H., Büttner, D.W., Eichner, M., 2003. Density-dependent parasite establishment suggests infection-associated immunosuppression as an important mechanism for parasite density regulation in onchocerciasis. Trans. R. Soc. Trop. Med. Hyg. 97 (2), 242-250.

Duerr, H.P., Dietz, K., Schulz-Key, H., Büttner, D.W., Eichner, M., 2004. The relationships between the burden of adult parasites, host age and the microfilarial density in human onchocerciasis. Int. J. Parasitol. 34 (4), 463-473.

Erttmann, K.D., Unnasch, T.R., Greene, B.M., Albiez, E.J., Boateng, J., Denke, A.M., Ferraronill, J.J., Karam, M., Schulz-Key, H., Williams, P.N., 1987. A DNA sequence specific for forest form Onchocerca volvulus. Nature 327 (6121), 415-417.

Erttmann, K.D., Meredith, S.E., Greene, B.M., Unnasch, T.R., 1990. Isolation and characterization of form specific DNA sequences of $O$. volvulus. Acta Leiden. 59 (1-2), 253-260.

Food and Agriculture Organization of the United Nations-Centre for International Cooperation in Agricultural Research for Development (FAO-CIRAD), 2012. Atlas of Trends in Pastoral Systems in the Sahel 1970-2012; FAO, Rome, 34 pp. Available: http://www.fao.org/3/a-i2601e.pdf. Accessed: 8 December 2020.

Filipe, J.A.N., Boussinesq, M., Renz, A., Collins, R.C., Vivas-Martinez, S., Grillet, M.E., Little, M.P., Basáñez, M.G., 2005. Human infection patterns and heterogeneous exposure in river blindness. Proc. Natl. Acad. Sci. U S A. 102 (42), 15265-15270.

Flockhart, H.A., Cibulskis, R., Karam, M., Albiez, E.J., 1986. Onchocerca volvulus: enzyme polymorphism in relation to the differentiation of forest and savannah strains of the parasite. Trans. R. Soc. Trop. Med. Hyg. 80 (2), 285-292.

Frentzel-Beyme, R., 1973. The prevalence of onchocerciasis and blindness in the population of the Bong Range, Liberia. Z. Tropenmed. Parasitol. 24 (3), 339-357.

Fryauff, D.J., Trpis, M., 1987. Quantitative studies of onchocerciasis transmission by Simulium yahense and Simulium sanctipauli in the Firestone Rubber Plantation at Harbel, Liberia. Am. J. Trop. Med. Hyg. 36(3), 561-572.

Fuglsang, H., Anderson, J., Marshall, T.F. de C., 1976. The head nodule and ocular onchocerciasis in Africa. Tropenmed. Parasitol. 27 (3), 355-364.

Garms, R., 1987. Infection rates and parasitic loads of Onchocerca volvulus, and other filariae, in Simulium sanctipauli s.1. and S. yahense in a rain-forest area of Liberia. Trop. Med. Parasitol. 38 (3), 201-204. 
Garms, R., Cheke, R.A., 1985. Infections with Onchocerca volvulus in different members of the Simulium damnosum complex in Togo and Benin. Z. Angew. Zool. 72, 479-495.

Garms, R., Walsh, J.F., Davies, J.B., 1979. Studies on the reinvasion of the Onchocerciasis Control Programme in the Volta River Basin by Simulium damnosum s.l. with emphasis on the south-western areas. Tropenmed. Parasitol. 30 (3), 345-362.

Garner, A., Duke, B.O.L., Anderson, J., 1973. A comparison of the lesions produced in the cornea of the rabbit eye by microfilariae of the forest and Sudan-savanna strains of Onchocerca volvulus from Cameroon. II. The pathology. Z. Tropenmed. Parasitol. 24 (4), 385-396.

Gbakima, A.A., Barbe, R.F., 1992. Onchocerca volvulus infection in Sierra Leone: relation between prevalence, intensity of infection, and ocular problems in a 'forest' region. Acta Leiden. 60 (2), 47-59.

GBD 2017 DALYs and HALE Collaborators, 2018. Global, regional, and national disabilityadjusted life-years (DALYs) for 359 diseases and injuries and healthy life expectancy (HALE) for 195 countries and territories, 1990-2017: a systematic analysis for the Global Burden of Disease Study 2017. Lancet. 392 (10159), 1859-1922.

GBD 2019 Cause and Risk Summaries, 2020. Onchocerciasis - Level 3 cause. Lancet. 396 (10258), S22-S23. Available: https://www.thelancet.com/pbassets/Lancet/gbd/summaries/diseases/onchocerciasis.pdf. Accessed 7 December 2020.

Hall, M., Clark, B., Rogers, M., Martín-Vega, D., Ghosh, D., Cheke, R., Veriegh, F., TettehKumah, T., Osei-Atweneboana, M.Y., 2020. Micro-CT visualisation of the parasitehost interface in sandflies and blackflies. London Centre for Neglected Tropical Disease Research. Available: https://www.londonntd.org/publications/micro-ctvisualisation-of-the-parasite-host-interface-in-sandflies-and-blackflies. Accessed: 8 December 2020.

Hamley, J.I.D., Milton, P., Walker, M., Basáñez, M.G., 2019. Modelling exposure heterogeneity and density dependence in onchocerciasis using a novel individual-based transmission model, EPIONCHO-IBM: implications for elimination and data needs. PLoS Negl. Trop. Dis. 13 (12), e0007557.

Hamley, J.I.D., Walker, M., Coffeng, L.E., Milton, P., de Vlas, S.J., Stolk, W.A., Basáñez, M.G., 2020. Structural uncertainty in onchocerciasis transmission models influences the estimation of elimination thresholds and selection of age groups for seromonitoring. J. Infect. Dis. 221 (Suppl 5), S510-S518. 
Hedtke, S.M., Kuesel, A.C., Crawford, K.E., Graves, P.M., Boussinesq, M., Lau, C.L., Boakye, D.A., Grant, W.N., 2020. Genomic epidemiology in filarial nematodes: transforming the basis for elimination program decisions. Front. Genet. 10, 1282.

Herricks, J.R., Hotez, P.J., Wanga, V., Coffeng, L.E., Haagsma, J.A., Basáñez, M.G., Buckle, G., Budke, C.M., Carabin, H., Fèvre, E.M., Fürst, T., Halasa, Y.A., King, C.H., Murdoch, M.E., Ramaiah, K.D., Shepard, D.S., Stolk, W.A., Undurraga, E.A., Stanaway, J.D., Naghavi, M., Murray, C.J.L., 2017. The global burden of disease study 2013: What does it mean for the NTDs? PLoS Negl. Trop. Dis. 11 (8), e0005424.

Higazi, T.B., Filiano, A., Katholi, C.R., Dadzie, Y., Remme, J.H., Unnasch, T.R., 2005. Wolbachia endosymbiont levels in severe and mild strains of Onchocerca volvulus. Mol. Biochem. Parasitol. 141 (1), 109-112.

Holland, S., 2017. Transformations of proportions and percentages. In: Data Analysis in the Geosciences. Available: http://strata.uga.edu/8370/rtips/proportions.html. Accessed: 8 December 2020.

Hopkins, A., Boatin, B.A., 2011. Chapter 11: Onchocerciasis. In: Selendy, J.M.H. (Ed.), Water and Sanitation-Related Diseases and the Environment: Challenges, Interventions, and Preventive Measures, 1st Edition. John Wiley \& Sons, Inc., pp. 133-149.

Hougard, J.M., Alley, E.S., Yaméogo, L., Dadzie, K.Y., Boatin, B.A., 2001. Eliminating onchocerciasis after 14 years of vector control: a proved strategy. J. Infect. Dis. 184 (4), 497-503.

Jacob, B.G., Loum, D., Lakwo, T.L., Katholi, C.R., Habomugisha, P., Byamukama, E., Tukahebwa, E., Cupp, E.W., Unnasch, T.R., 2018. Community-directed vector control to supplement mass drug distribution for onchocerciasis elimination in the Madi midNorth focus of Northern Uganda. PLoS Negl. Trop. Dis. 12 (8), e0006702.

Jacobi, C.A., Enyong, P., Renz, A., 2010. Individual exposure to Simulium bites and intensity of Onchocerca volvulus infection. Parasit. Vectors. 3, 53.

Kashan, A., Garms, R., 1987. Cytotaxonomy of the Simulium sanctipauli sub-complex in Liberia. Trop. Med. Parasitol. 38 (4), 289-293.

Kamgno, J., Pion, S.D., Chesnais, C.B., Bakalar, M.H., D'Ambrosio, M.V., Mackenzie, C.D., Nana-Djeunga, H.C., Gounoue-Kamkumo, R., Njitchouang, G.R., Nwane, P., Tchatchueng-Mbouga, J.B., Wanji, S., Stolk, W.A., Fletcher, D.A., Klion, A.D., Nutman, T.B., Boussinesq, M., 2017 A Test-and-Not-Treat strategy for onchocerciasis in Loa loa-endemic areas. N. Engl. J. Med. 377 (21), 2044-2052 
Katabarwa, M., Richards, F., 2014. Twice-yearly ivermectin for onchocerciasis: the time is now. Lancet Infect. Dis. 14(5), 373-374.

Katabarwa, M.N., Lakwo, T., Habomugisha, P., Unnasch, T.R., Garms, R., Hudson-Davis, L., Byamukama, E., Khainza, A., Ngorok, J., Tukahebwa, E., Richards, F.O., 2018. After 70 years of fighting an age-old scourge, onchocerciasis in Uganda, the end is in sight. Int. Health. 10 (Suppl 1), i79-i88.

Kayembe, D.L., Kasonga, D.L., Kayembe, P.K., Mwanza, J.-C. K., Boussinesq, M., 2003. Profile of eye lesions and vision loss: a cross-sectional study in Lusambo, a forestsavanna area hyperendemic for onchocerciasis in the Democratic Republic of Congo. Trop. Med. Int. Health. 8 (1), 83-89.

Keddie, E.M., Higazi, T., Boakye, D., Merriweather, A., Wooten, M.C., Unnasch, T.R., 1999. Onchocerca volvulus: limited heterogeneity in the nuclear and mitochondrial genomes. Exp. Parasitol. 93 (4): 198-206.

Kirkwood, B., Sterne, J.A.C., 2003. Medical Statistics. 2nd. edition. Blackwell Science, Oxford, UK.

Koala, L., Nikièma, A., Post, R.J., Pare, A.B., Kafando, C.M., Drabo, F., Traoré, S., 2017. Recrudescence of onchocerciasis in the Comóe valley in southwest Burkina Faso. Acta Trop. 166, 96-105.

Kostalova, T., Lestinova, T., Sumova, P., Vlkova, M., Rohousova, I., Berriatua, E., Oliva, G., Fiorentino, E., Scalone, A., Gramiccia, M., Gradoni, L., Volf, P., 2015. Canine antibodies against salivary recombinant proteins of Phlebotomus perniciosus: a longitudinal study in an endemic focus of canine leishmaniasis. PLoS Negl. Trop. Dis. 9 (6), e0003855.

Kuper, H., Solomon, A.W., Buchan, J., Zondervan, M., Foster, A., Mabey, D., 2003. A critical review of the SAFE strategy for the prevention of blinding trachoma. Lancet Infect. Dis. 3 (6), 372-381.

Lewis, D.J., Duke, B.O.L., 1966. Onchocerca-Simulium complexes. II. Variation in West African female Simulium damnosum. Ann. Trop. Med. Parasitol 60 (3), 337-346. Little, K.E., Basáñez, M.G., Little, M.P., Cheke, R.A., 2003. Patterns of blindness due to human onchocerciasis: a whole new can of worms. Br. Simuliid Group Bull. 21, 10-12. Little, M.P., Basáñez, M.-G., Breitling, L.P.H., Boatin, B.A., Alley, E.S., 2004a. Incidence of blindness during the Onchocerciasis Control Programme in Western Africa, 1971-2002. J. Infect. Dis. 189 (10), 1932-1941. 
Little, M.P, Breitling, L.P., Basáñez, M.G., Alley, E.S., Boatin, B.A., 2004b. Association between microfilarial load and excess mortality in onchocerciasis: an epidemiological study. Lancet. 363 (9420), 1514-1521.

Mas, J., Yumbe, A., Solé, N., Capote, R., Cremades, T., 1995. Prevalence, geographical distribution and clinical manifestations of onchocerciasis on the Island of Bioko (Equatorial Guinea). Trop. Med. Parasitol. 46 (1), 13-18.

McMahon, J.E., Sowa, S.I.C., Maude, G.H., Kirkwood, B., 1988. Onchocerciasis in Sierra Leone 2: A comparison of forest and savanna villages. Trans. R. Soc. Trop. Med. Hyg. $82(4), 595-600$.

Mendoza Aldana, J., Piechulek, H., Maguire, J., 1997. Forest onchocerciasis in Cameroon: its distribution and implications for selection of communities for control programmes. Ann. Trop. Med. Parasitol. 91 (1), 79-86.

Meredith, S.E., Lando, G., Gbakima, A.A., Zimmerman, P.A., Unnasch, T.R., 1991. Onchocerca volvulus: application of the polymerase chain reaction to identification and strain differentiation of the parasite. Exp. Parasitol. 73 (3), 335-344.

Merriweather, A., Unnasch, T.R., 1996. Onchocerca volvulus: development of a speciesspecific polymerase chain reaction-based assay. Exp. Parasitol. 83 (1), 164-166.

Milton, P., Hamley, J.I.D., Walker, M., Basáñez, M.G., 2020. Moxidectin: an oral treatment for human onchocerciasis. Expert Rev. Anti Infect. Ther. 18(11), 1067-1081.

Morales-Hojas, R., Cheke, R.A., Post, R.J., 2006. The molecular systematics of five Onchocerca species (Nematoda: Filarioidea) including the human parasite, O. volvulus, suggest sympatric speciation. J. Helminthol. 80 (3), 281-290.

Morales-Hojas, R., Cheke, R.A., Post, R.J., 2007. A preliminary analysis of the population genetics and molecular phylogenetics of Onchocerca volvulus (Nematoda: Filarioidea) using nuclear ribosomal second internal transcribed spacer sequences. Mem. Inst. Oswaldo Cruz. 102 (7), 879-882.

Moreau, J.P., Prost, A., Prod'hon, J., 1978. [An attempt to normalize the methodology of clinico parasitologic surveys of onchocerciasis in West-Africa]. Med. Trop. (Mars.). 38 (1), 43-51 (in French).

Murdoch, M.E., Hay, R.J., Mackenzie, C.D., Williams, J.F., Ghalib, H.W., Cousens, S., Abiose, A., Jones, B.R., 1993. A clinical classification and grading system of the cutaneous changes in onchocerciasis. Br. J. Dermatol. 129 (3), 260-269.

Mustapha, M., Post, R.J., Enyong, P., Lines, J., 2004. A new cytotype of Simulium squamosum from southwest Cameroon. Med. Vet. Entomol. 18 (3), 296-300. 
Nnochiri, E., 1964. Observations on onchocercal lesions seen in autopsy specimens in western Nigeria. Ann. Trop. Med. Parasitol. 58 (1): 89-93.

NTD Modelling Consortium Onchocerciasis Group, 2019. The World Health Organization 2030 goals for onchocerciasis: Insights and perspectives from mathematical modelling. Gates Open Res. 3, 1545.

Ogunrinade, A., Boakye, D., Merriweather, A., Unnasch, T.R., 1999. Distribution of the blinding and nonblinding strains of Onchocerca volvulus in Nigeria. J. Infect. Dis. 179 (6), 1577-1579.

O'Hanlon, S.J., Slater, H.C., Cheke, R.A., Boatin, B.A., Coffeng, L.E., Pion, S.D.S., Boussinesq, M., Zouré, H.G.M., Stolk, W.A., Basáñez, M.G., 2016. Model-based geostatistical mapping of the prevalence of Onchocerca volvulus in West Africa. PLoS Negl. Trop. Dis. 10 (1), e0004328.

Pearlman, E., Gillette-Ferguson, I., 2007. Onchocerca volvulus, Wolbachia and river blindness. Chem. Immunol. Allergy 92, 254-265.

Philippon, B., 1977. Étude de la transmission d'Onchocerca volvulus Leuckart 1893 (Nematoda, Onchocercidae) par Simulium damnosum Theobald 1903 (Diptera: Simuliidae), en Afrique tropicale. Trav. Doc. O.R.S.T.O.M. (Paris) No. 63.

Philippon, B., Bain, O., 1972. Transmission de l'onchocercose humaine en zone de savane d'Afrique Occidentale, passage des microfilaires d'Onchocerca volvulus Leuck. dans l'hémocèle de la femelle de Simulium damnosum Th. Cah. O.R.S.T.O.M., Sér. Entomol. Méd. Parasitol. 10, 251-261.

Pion, S.D.S., Kamgno, J., Demanga-Ngangue, Boussinesq, M., 2002. Excess mortality associated with blindness in the onchocerciasis focus of the Mbam Valley, Cameroon. Ann. Trop. Med. Parasitol. 96 (2), 181-189.

Post, R.J., 1986. Cytotaxonomy of Simulium sanctipauli and Simulium soubrense (Diptera: Simuliidae). Genetica 69 (3), 191-207.

Post, R.J., Flook, P.K., Millest, A.L., Cheke, R.A., McCall, P.J., Wilson, M.D., Mustapha, M., Somiari, S., Davies, J.B., Mank, R.A., Geenen, P., Enyong, P., Sima, A., Mas, J., 2003. Cytotaxonomy, morphology and molecular systematics of the Bioko form of Simulium yahense (Diptera: Simuliidae). Bull. Entomol. Res. 93 (2), 145-157.

Quillévéré, D., 1979. Contribution à l'étude des charactéristiques taxonomiques, bioécologiques et vectrices des members du complexe Simulium damnosum presents en Côte d'Ivoire. Trav. Doc. O.R.S.T.O.M. (Paris) No. 109. 
Quinnell, R.J., Soremekun, S., Bates, P.A., Rogers, M.E., Garcez, L.M., Courtenay, O., 2018. Antibody response to sand fly saliva is a marker of transmission intensity but not disease progression in dogs naturally infected with Leishmania infantum. Parasit. Vectors. 11(1), 7.

R Core Team, 2019. The R Project for Statistical Computing. The R Foundation. Available: https://www.R-project.org/. Accessed: 8 December 2020.

Remme, J., Ba, O., Dadzie, K.Y., Karam, M., 1986. A force-of-infection model for onchocerciasis and its applications in the epidemiological evaluation of the Onchocerciasis Control Programme in the Volta river basin area. Bull. World Health Organ. 64 (5), 667-681.

Remme, J., Dadzie, K.Y., Rolland, A., Thylefors, B., 1989. Ocular onchocerciasis and intensity of infection in the community. I. West African savanna. Trop. Med. Parasitol. 40 (3): 340-347.

Renz, A., 1987. Studies on the dynamics of transmission of onchocerciasis in a Sudansavanna area of North Cameroon III. Infection rates of the Simulium vectors and Onchocerca volvulus transmission potentials. Ann. Trop. Med. Parasitol. 81 (3), 239252.

Renz, A., Wenk, P., 1987, Studies on the dynamics of transmission of onchocerciasis in a Sudan-savanna area of North Cameroon I. Prevailing Simulium vectors, their biting rates and age-composition at different distances from their breeding sites. Ann. Trop. Med. Parasitol. 81 (3), 215-228.

Renz, A., Fuglsang, H., Anderson, J., 1987a. Studies on the dynamics of transmission of onchocerciasis in a Sudan-savanna area of North Cameroon IV. The different exposure to Simulium bites and transmission of boys and girls and men and women, and the resulting manifestations of onchocerciasis. Ann. Trop. Med. Parasitol. 81 (3), 253-262.

Renz, A., Wenk, P., Anderson, J., Fuglsang, H., 1987b. Studies on the dynamics of transmission of onchocerciasis in a Sudan-savanna area of North Cameroon V. What is a tolerable level of Annual Transmission Potential? Ann. Trop. Med. Parasitol. 81 (3), 263-274.

Routledge, I., Walker, M., Cheke, R.A., Bhatt, S., Nkot, P.B., Matthews, G.A., Baleguel, D., Dobson, H.M., Wiles, T.L., Basañez, M.G., 2018. Modelling the impact of larviciding on the population dynamics and biting rates of Simulium damnosum (s.1.): implications for vector control as a complementary strategy for onchocerciasis elimination in Africa. Parasit. Vectors. 11 (1), 316. 
Saint André, A.V., Blackwell, N.M., Hall, L.R., Hoerauf, A., Brattig, N.W., Volkmann, L., Taylor, M.J., Ford, L., Hise, A.G., Lass, J.H., Diaconu, E., Pearlman, E., 2002. The role of endosymbiotic Wolbachia bacteria in the pathogenesis of river blindness. Science. 295 (5561), 1892-1895.

Smith, M.E., Bilal, S., Lakwo, T.L., Habomugisha, P., Tukahebwa, E., Byamukama, E, Katabarwa, M.N., Richards, F.O., Cupp, E.W., Unnasch, T.R., Michael, E., 2019. Accelerating river blindness elimination by supplementing MDA with a vegetation "slash and clear" vector control strategy: a data-driven modeling analysis. Sci. Rep. 9(1), 15274.

Soumbey-Alley, E., Basáñez, M.G., Bissan, Y., Boatin, B.A., Remme, J.H.F., Nagelkerke, N.J.D., de Vlas, S.J., Borsboom, G.J.J.M., Habbema, J.D.F., 2004. Uptake of Onchocerca volvulus (Nematoda: Onchocercidae) by Simulium (Diptera: Simuliidae) is not strongly dependent on the density of skin microfilariae in the human host. J. Med. Entomol. 41 (1), 83-94.

Stolk, W.A., Walker, M., Coffeng, L.E., Basáñez, M.G., de Vlas, S.J., 2015. Required duration of mass ivermectin treatment for onchocerciasis elimination in Africa: a comparative modelling analysis. Parasit. Vectors. 8, 552.

Tamarozzi, F., Halliday, A., Gentil, K., Hoerauf, A., Pearlman, E., Taylor, M.J., 2011. Onchocerciasis: the role of Wolbachia bacterial endosymbionts in parasite biology, disease pathogenesis, and treatment. Clin. Microbiol. Rev. 24 (3), 459-468.

Taylor, M.J., Bandi, C., Hoerauf, A., 2005. Wolbachia bacterial endosymbionts of filarial nematodes. Adv. Parasitol. 60, 245-284.

Thylefors, B., Philippon, B., Prost, A., 1978. Transmission potentials of Onchocerca volvulus and the associated intensity of onchocerciasis in a Sudan-savanna area. Tropenmed. Parasitol. 29 (3), 346-354.

Thylefors, B., Dawson, C.R., Jones, B.R., West, S.K., Taylor, H.R., 1987. A simple system for the assessment of trachoma and its complications. Bull. World Health Organ. 65 (4), 477-483.

Toé, L., Merriweather, A., Unnasch, T.R., 1994. DNA probe-based classification of Simulium damnosum s. 1.-borne and human-derived filarial parasites in the onchocerciasis control program area. Am. J. Trop. Med. Hyg. 51 (5), 676-683.

Toé, L., Tang, J., Back, C., Katholi, C.R., Unnasch, T.R., 1997. Vector-parasite transmission complexes for onchocerciasis in West Africa. Lancet. 349 (9046): 163-166. 
Traoré, S., Wilson, M.D., Sima, A., Barro, T., Diallo, A., Aké, A., Coulibaly, S., Cheke, R.A., Meyer, R., Mas, J., McCall, P.J., Post, R.J., Zouré, H., Noma, M., Yaméogo, L., Sékétéli, A.V., Amazigo, U.V., 2009. The elimination of the onchocerciasis vector from the island of Bioko as a result of larviciding by the WHO African Programme for Onchocerciasis Control. Acta Trop. 111 (3), 211-218.

Trpis M., 2006. Consequences of vector behavior in epidemiology of onchocerciasis on the Firestone Rubber Plantation in Liberia. Am. J. Trop. Med. Hyg. 74 (5), 833-840. Turner, H.C., Walker, M., Attah, S.K., Opoku, N.O., Awadzi, K., Kuesel, A.C., Basáñez, M.G., 2015. The potential impact of moxidectin on onchocerciasis elimination in Africa: an economic evaluation based on the Phase II clinical trial data. Parasit. Vectors. 8, 167.

Turner, H.C., Osei-Atweneboana M.Y., Walker, M., Tettevi, E.J., Churcher, T.S., Asiedu, O., Biritwum, N.K., Basáñez, M.G., 2013. The cost of annual versus biannual communitydirected treatment of onchocerciasis with ivermectin: Ghana as a case study. PLoS Negl. Trop. Dis. 7 (9), e2452.

Umeh, R.E., Chijioke, C.P., Okonkwo, P.O., 1996. Eye disease in an onchocerciasis-endemic area of the forest-savanna mosaic region of Nigeria. Bull. World Health Organ. 74 (1), 95-100.

Vajime, C.G., Dunbar, R.W., 1975. Chromosomal identification of eight species of the subgenus Edwardsellum near and including Simulium (Edwardsellum) damnosum Theobald (Diptera: Simuliidae). Tropenmed. Parasitol. 26 (1), 111-138.

Verver, S., Walker, M., Kim, Y.E., Fobi, G., Tekle, A.H., Zouré, H.G.M., Wanji, S., Boakye, D.A., Kuesel, A.C., de Vlas, S.J., Boussinesq, M., Basáñez, M.G., Stolk, W.A., 2018. How can onchocerciasis elimination in Africa be accelerated? Modeling the impact of increased ivermectin treatment frequency and complementary vector control. Clin. Infect. Dis. 66 (Suppl 4), S267-S274.

Vinkeles Melchers, N.V.S., Mollenkopf, S., Colebunders, R., Edlinger, M., Coffeng, L.E., Irani, J., Zola, T., Siewe, J.N., de Vlas, S.J., Winkler, A.S., Stolk, W.A., 2018. Burden of onchocerciasis-associated epilepsy: first estimates and research priorities. Infect. Dis. Poverty. 7 (1), 101.

Walker, M., Little, M.P., Wagner, K.S., Soumbey-Alley, E.W., Boatin, B.A., Basáñez, M.G., 2012. Density-dependent mortality of the human host in onchocerciasis: relationships between microfilarial load and excess mortality. PLoS Negl. Trop. Dis. 6 (3), e1578. 
Walker, M., Specht, S., Churcher, T.S., Hoerauf, A., Taylor, M.J., Basáñez, M.G., 2015. Therapeutic efficacy and macrofilaricidal activity of doxycycline for the treatment of river blindness. Clin. Infect. Dis. 60 (8), 1199-1207.

Walker, M., Stolk, W.A., Dixon, M.A., Bottomley, C., Diawara, L., Traoré, M.O., de Vlas, S.J., Basáñez, M.G., 2017. Modelling the elimination of river blindness using long-term epidemiological and programmatic data from Mali and Senegal. Epidemics. 18, 4-15.

Walsh, J.F., Davies, J.B., LeBerre, R., 1979. Entomological aspects of the first five years of the Onchocerciasis Control Programme in the Volta river basin. Tropenmed. Parasitol. $30(3), 328-344$.

Wanji, S., Kengne-Ouafo, J.A., Esum, M.E., Chounna, P.W., Tendongfor, N., Adzemye, B.F., Eyong, J.E., Jato, I., Datchoua-Poutcheu, F.R., Kah, E., Enyong, P., Taylor, D.W., 2015. Situation analysis of parasitological and entomological indices of onchocerciasis transmission in three drainage basins of the rain forest of South West Cameroon after a decade of ivermectin treatment. Parasit. Vectors. 8, 202.

Wanji, S., Nji, T.M., Hamill, L., Dean, L., Ozano, K., Njouendou, A.J., Abong, R.A., Obie, E.D., Amuam, A., Ekanya, R., Ndongmo, W.P.C., Ndzeshang, B.L., Fung, E.G., Nnamdi, D.B., Nkimbeng, D.A., Teghen, S., Kah, E., Piotrowski, H., Forrer, A., Khan, J.A.M., Woode, M.E., Niessen, L., Watson, V., Njoumemi, Z., Murdoch, M.E., Thomson, R., Theobald, S., Enyong, P., Turner, J.D., Taylor, M.J., 2019 Implementation of test-and-treat with doxycycline and temephos ground larviciding as alternative strategies for accelerating onchocerciasis elimination in an area of loiasis co-endemicity: the COUNTDOWN consortium multi-disciplinary study protocol. Parasit. Vectors. 12, 574.

White, F. 1983. Vegetation of Africa-a descriptive memoir to accompany the UNESCO/AETFAT/UNSO vegetation map of Africa. Natural Resources Research Report XX. U.N. Educational, Scientific and Cultural Organization; 7 Place de Fontenoy, 75700 Paris, France, 356 pp.

Winnen, M., Plaisier, A.P., Alley, E.S., Nagelkerke, N.J.D., van Oortmarssen, G., Boatin, B.A., Habbema, J.D.F., 2002. Can ivermectin mass treatments eliminate onchocerciasis in Africa? Bull. World Health Organ. 80 (5), 384-391.

World Health Organization, 1987. WHO Expert Committee on Onchocerciasis (meeting held in Geneva from 21 to 29 April 1986). Third Report. Technical Report Series 752. 167pp. World Health Organization, Geneva, Switzerland. Available: https://apps.who.int/iris/handle/10665/38959. Accessed: 8 December 2020. 
World Health Organization, 1995. Onchocerciasis and its control. Report of a WHO expert committee on onchocerciasis control. WHO Technical Report Series, number 852. Geneva: World Health Organization, Geneva, Switzerland. 110 pp. Available: https://apps.who.int/iris/handle/10665/37346. Accessed: 8 December 2020.

World Health Organization, 2017. 681 Progress report on the elimination of human onchocerciasis, 2016-2017. Wkly. Epidemiol. Rec. 92 (45), 681-694.

World Health Organization, 2020. Ending the neglect to attain the Sustainable Development Goals. A road map for neglected tropical diseases 2021-2030. Available: https://www.who.int/neglected_diseases/Ending-the-neglect-to-attain-the-SDGs--NTDRoadmap.pdf?ua=1. Accessed: 8 December 2020.

Zachariah, K.C., Condé, J. 1981. Migration in West Africa: Demographic Aspects. A Joint World Bank-OECD Study. The World Bank, Oxford University Press. Available: http://documents.worldbank.org/curated/en/950061468742878256/pdf/multi-page.pdf. Accessed: 8 December 2020.

Zimmerman, P.A., Dadzie, K.Y., De Sole, G., Remme, J., Soumbey Alley, E. Unnasch, T.R., 1992. Onchocerca volvulus DNA probe classification correlates with epidemiologic patterns of blindness. J. Infect. Dis. 165 (5), 964-968.

Zimmerman, P.A., Katholi, C.R., Wooten, M.C., Lang-Unnasch, N., Unnasch, T.R., 1994. Recent evolutionary history of American Onchocerca volvulus, based on analysis of a tandemly repeated DNA sequence family. Mol. Biol. Evol. 11(3): 384-392.

Zouré, H.G.M., Noma, M., Tekle, A.H., Amazigo, U.V., Diggle, P.J., Giorgi, E., Remme, J.H.F., 2014. The geographic distribution of onchocerciasis in the 20 participating countries of the African Programme for Onchocerciasis Control: (2) pre-control endemicity levels and estimated number infected. Parasit. Vectors. 7, 326. 
Table 1 Ocular manifestations of trachoma, loiasis and onchocerciasis

\section{Trachoma}

(bacterium: Chlamydia trachomatis)
African eyeworm (filarial nematode: Loa loa)
River blindness

(filarial nematode: Onchocerca volvulus)
Mode of transmission

Chronic follicular keratoconjunctivitis spread from eye to eye by Musca sorbens flies (mechanical vectors), fingers, fomites, and possibly by coughing and sneezing

\section{Disease mechanism and ocular manifestations}

Repeated infections cause chronic inflammation, particularly of the tarsal conjunctiva underlying the upper eyelid producing scarring that leads to eye lashes turning inwards (trichiasis) and rubbing against the cornea, damaging the corneal surface, and leading to corneal opacification and blindness

Grading and ocular disease progression Simplified WHO Grading System:
Five or more follicles
Chronic filarial infection transmitted from person to person via the bites of tabanid flies of the genus Chrysops (biological vectors). Main vectors among humans are Ch. silacea and $C h$. dimidiata

\section{Typical ocular manifestations ('eye worm')}

Passage of the adult worm under the (bulbar or papebral) conjunctiva of the eye. Migration of the worm under bulbar conjunctiva ranges from 0.5 $>24 \mathrm{hr}$; accompanied by eye congestion, pruritus and photophobia. Less frequent passage under palpebral conjunctiva is associated with palpebral or periorbital oedema

\section{Atypical ocular manifestations}

L. loa adult worms can be found in anterior
(Pan)uveitis, iridocyclitis, vitreous haze,
Chronic filarial infection transmitted from person to person via the bites of blackflies of the genus Simulium (biological vectors). Main vectors in Africa are S. damnosum s.l. and S. neavei s.l.

\section{Disease mechanism and ocular manifestations}

$O$. volvulus microfilariae can be found in all eye tissues, from the conjunctiva anteriorly, to the optic nerve posteriorly. Eye disease worsens progressively with parasite exposure and eventually leads to blindness. Ocular lesions range from punctate and sclerosing keratitis (anterior segment) to optic nerve atrophy (posterior segment). Anterior chamber lesions result from repeated inflammatory processes triggered by filarial and Wolbachia products released by dying microfilariae. Pathogenesis of retinal lesions may result from autoimmune processes elicited by cross-reactivity between $O$. volvulus antigen Ov39 and human retinal antigen hr44

\section{Anterior and posterior eye involvement}

MFAC: Microfilariae Microfilariae can be in anterior chamber seen with a slit lamp in 
TF: Trachomatous

inflammation follicular

of $>0.5 \mathrm{~mm}$ on the

upper tarsal

conjunctiva chamber of the eye or extending from anterior

to posterior chamber corneal oedema,

corneal opacity,

macular chorioretinitis,

macular degeneration,

retinal detachment

unilateral and bilateral

blurring/ reduction/loss

of vision
TI: Trachomatous

inflammation intense

TS: Trachomatous scarring
Papillary hypertrophy

and inflammatory

thickening of the upper

tarsal conjunctiva

obscuring more than

half the deep tarsal

vessels

Presence of scarring in

tarsal conjunctiva the aqueous humour, sticking to the inner surface of the cornea, the endothelium, and in severe cases in the bottom of the anterior chamber, forming a mass, called pseudohypopyon.

Microfilariae can also penetrate the iris and cause chronic anterior uveitis. This can lead to blindness due to secondary glaucoma or cataract. The pupil shrinks, deforms and sticks to the lens (posterior synechiae)

PK: Punctate keratitis

Microfilariae can invade the cornea where as they die, provoke punctuate keratitis, a white (fluffy) inflammatory reaction

SK: Sclerosing keratitis and $\mathrm{CO}$ : corneal opacity
It begins at the 3 and 9 o'clock positions of the eye, gradually filling in from the bottom, creating a semilunar 


\section{TT: Trachomatous} trichiasis

CO: Corneal opacity

\begin{abstract}
$\geq 1$ ingrown eyelash touching the globe; evidence of epilation
\end{abstract} (eyelash removal)

Corneal opacity blurring part of the pupil margin;

eventually leading to

blindness keratitis until the whole

cornea is affected

(CO), eventually leading to blindness

Posterior segment

Microfilariae can be seen in the vitreous. The most serious aspects of posterior segment disease are chronic chorioretinitis and optic nerve atrophy. The macula (central vision) is initially spared, but eventually central vision is lost. Optic nerve atrophy leads to blindness

For trachoma, see review by Kuper, H., Solomon, A.W., Buchan, J., Zondervan, M., Foster, A., Mabey, D., 2003. A critical review of the SAFE strategy for the prevention of blinding trachoma. Lancet Infect. Dis. 3 (6), 372-381; for WHO trachoma grading system see Thylefors, B., Dawson, C.R., Jones, B.R., West, S.K., Taylor, H.R., 1987. A simple system for the assessment of trachoma and its complications. Bull. World Health Organ. 65 (4), $477-483$.

For loiasis, see review by Boussinesq, M., 2006. Loiasis. Ann. Trop. Med. Parasitol. 100 (8), 715-731; for atypical loiasis manifestations see Buell, K.G., Whittaker, C., Chesnais, C.B., Jewell, P.D., Pion, S.D.S., Walker, M., Basáñez, M.G., Boussinesq, M., 2019. Atypical clinical manifestations of loiasis and their relevance for endemic populations. Open Forum Infect. Dis. 6 (11), ofz417.

For onchocerciasis, see reviews by Basáñez, M.G., Pion, S.D.S., Churcher, T.S., Breitling, L.P., Little, M.P., Boussinesq M., 2006. River blindness: a success story under threat? PLoS Med. 3 (9), e371; Hopkins, A., Boatin, B.A., 2011. Chapter 11: Onchocerciasis. In: Selendy, J.M.H. (Ed.), Water and SanitationRelated Diseases and the Environment: Challenges, Interventions, and Preventive Measures, 1st Edition. John Wiley \& Sons, Inc., pp. $133-149$. 
Table 2 Data sources according to country, habitat, vectors, annual transmission potential (ATP), number of people examined, standardised microfilarial prevalence, percent bilateral blindness, causes of blindness and references

\begin{tabular}{|c|c|c|c|c|c|c|c|c|c|c|c|c|c|c|c|c|c|c|c|c|c|}
\hline Country & Habitat & 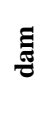 & $\stackrel{?}{\vec{n}}$ & 窇 & $\overline{\bar{z}}$ & 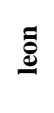 & 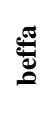 & 薦 & స్ & $\bar{\Xi}$ & ATP & $\begin{array}{l}\text { No. } \\
\text { people } \\
\text { exam. }\end{array}$ & $\begin{array}{l}\text { No. } \\
\text { +ve } \\
\text { for } \mathrm{mf}\end{array}$ & $\begin{array}{l}\text { mf } \\
\text { prev. } \\
(\% \mathrm{mf})\end{array}$ & $\begin{array}{l}\text { Stand. } \\
\text { mf } \\
\text { prev. }\end{array}$ & $\begin{array}{l}\text { No. people } \\
\text { exam. for } \\
\text { blindness }\end{array}$ & $\begin{array}{l}\text { No. } \\
\text { blind }\end{array}$ & $\begin{array}{l}\% \\
\text { blind- } \\
\text { ness }\end{array}$ & $\begin{array}{l}\text { Stand. \% } \\
\text { bilateral } \\
\text { blindness }\end{array}$ & $\begin{array}{l}\text { Causes of } \\
\text { blindness }\end{array}$ & Reference \\
\hline Benin & mosaic & 1 & 1 & 1 & 0 & $\overline{0}$ & 1 & $\overline{0}$ & 0 & $\overline{0}$ & & 1,993 & & & 21.3 & 1,993 & & & $0.28^{*}$ & oncho & $\begin{array}{l}\text { De Sole et al. } \\
\text { (1992) }\end{array}$ \\
\hline Benin & savannah & 1 & 1 & 1 & 0 & 0 & 1 & 0 & 0 & 0 & & 440 & & & 23.7 & 440 & & & $0.34 *$ & oncho & $\begin{array}{l}\text { De Sole et al. } \\
\text { (1992) }\end{array}$ \\
\hline Benin & savannah & 1 & 1 & 0 & 0 & 0 & 1 & 0 & 0 & 0 & & 606 & & & 32.5 & 606 & & & $0.43 *$ & oncho & $\begin{array}{l}\text { De Sole et al. } \\
\text { (1992) }\end{array}$ \\
\hline $\begin{array}{l}\text { Burkina } \\
\text { Faso }\end{array}$ & savannah & 0 & 0 & 1 & 0 & 0 & 0 & 0 & 0 & 0 & 959 & 234 & & 70.3 & 70.3 & 182 & & 2.1 & 2.1 & oncho & $\begin{array}{l}\text { Thylefors et } \\
\text { al. (1978) }\end{array}$ \\
\hline $\begin{array}{l}\text { Burkina } \\
\text { Faso }\end{array}$ & savannah & 1 & 1 & 0 & 0 & 0 & 0 & 0 & 0 & 0 & 222 & 508 & & 54.8 & 54.8 & 378 & & 0.2 & 0.2 & oncho & $\begin{array}{l}\text { Thylefors et } \\
\text { al. (1978) }\end{array}$ \\
\hline Cameroon & forest & 0 & 0 & 1 & 0 & 0 & 0 & 0 & 0 & 1 & 897 & 209 & 65 & 31.1 & 32.1 & 81 & 2 & 2.47 & 1.27 & all causes & $\begin{array}{l}\text { Duke et al. } \\
\text { (1972) }\end{array}$ \\
\hline Cameroon & forest & 0 & 0 & 1 & 0 & 0 & 0 & 0 & 0 & 1 & 2,806 & 143 & 91 & 63.6 & 65.6 & 69 & 4 & 5.80 & 5.09 & all causes & $\begin{array}{l}\text { Duke et al. } \\
\text { (1972) }\end{array}$ \\
\hline Cameroon & forest & 0 & 0 & 1 & 0 & 0 & 0 & 0 & 0 & 1 & 10,421 & 189 & 146 & 77.2 & 79.6 & 88 & 9 & 10.23 & 7.53 & all causes & $\begin{array}{l}\text { Duke et al. } \\
\text { (1972) }\end{array}$ \\
\hline Cameroon & forest & 0 & 0 & 1 & 0 & 0 & 0 & 0 & 0 & 1 & 87,846 & 161 & 115 & 71.4 & 73.6 & 73 & 6 & 8.22 & 4.33 & all causes & $\begin{array}{l}\text { Duke et al. } \\
\text { (1972) }\end{array}$ \\
\hline Cameroon & forest & 0 & 0 & 1 & 0 & 0 & 0 & 0 & 0 & 1 & & 1,151 & 1,098 & 95.4 & 92.4 & 1,098 & 22 & 2.0 & 2.0 & all causes & $\begin{array}{l}\text { Anderson et } \\
\text { al. (1974) }\end{array}$ \\
\hline Cameroon & forest & 0 & 0 & 1 & 0 & 0 & 0 & 0 & 0 & 1 & & 631 & & & 56.3 & 631 & & 2.0 & 2.0 & all causes & $\begin{array}{l}\text { Mendoza } \\
\text { Aldana et al. } \\
\text { (1997) }\end{array}$ \\
\hline Cameroon & forest & 0 & 0 & 1 & 0 & 0 & 0 & 0 & 0 & 1 & & 246 & & & 68.5 & 246 & & 3.2 & 3.2 & all causes & $\begin{array}{l}\text { Mendoza } \\
\text { Aldana et al. } \\
\text { (1997) }\end{array}$ \\
\hline Cameroon & forest & 0 & 0 & 1 & 0 & 0 & 0 & 0 & 0 & 1 & & 908 & & & 78.8 & 908 & & 2.9 & 2.9 & all causes & $\begin{array}{l}\text { Mendoza } \\
\text { Aldana et al. } \\
\text { (1997) }\end{array}$ \\
\hline Cameroon & savannah & 1 & 1 & 0 & 0 & 0 & 0 & 0 & 0 & 0 & & 1,220 & 1,128 & 92.5 & 91.8 & 1,128 & & 5.1 & 5.1 & all causes & $\begin{array}{l}\text { Anderson et } \\
\text { al. (1974) }\end{array}$ \\
\hline
\end{tabular}


Revisiting the Strain Hypothesis in Onchocerciasis

\begin{tabular}{|c|c|c|c|c|c|c|c|c|c|c|c|c|c|c|c|c|c|c|c|}
\hline Cameroon & savannah & 1 & 1 & 0 & 0 & 0 & 0 & 0 & 0 & 0 & 17 & 48 & 48.4 & 48.4 & 48 & 0.0 & 0.0 & all causes & $\begin{array}{l}\text { Renz et al. } \\
\text { (1987b) }\end{array}$ \\
\hline Cameroon & savannah & 1 & 1 & 0 & 0 & 0 & 0 & 0 & 0 & 0 & 49 & 88 & 50.7 & 50.7 & 88 & 0.0 & 0.0 & all causes & $\begin{array}{l}\text { Renz et al. } \\
\text { (1987b) }\end{array}$ \\
\hline Cameroon & savannah & 1 & 1 & 0 & 0 & 0 & 0 & 0 & 0 & 0 & 79 & 42 & 64.4 & 64.4 & 42 & 0.0 & 0.0 & all causes & $\begin{array}{l}\text { Renz et al. } \\
\text { (1987b) }\end{array}$ \\
\hline Cameroon & savannah & 1 & 1 & 0 & 0 & 0 & 0 & 0 & 0 & 0 & 500 & 125 & 89.2 & 89.2 & 125 & 0.0 & 0.0 & oncho & $\begin{array}{l}\text { Duke et al. } \\
\text { (1975) }\end{array}$ \\
\hline Cameroon & savannah & 1 & 1 & 0 & 0 & 0 & 0 & 0 & 0 & 0 & 55 & 93 & 60.8 & 60.8 & 93 & 0.0 & 0.0 & all causes & $\begin{array}{l}\text { Renz et al. } \\
\text { (1987b) }\end{array}$ \\
\hline Cameroon & savannah & 1 & 1 & 0 & 0 & 0 & 0 & 0 & 0 & 0 & 77 & 67 & 74.1 & 74.1 & 67 & 4.5 & 4.5 & all causes & $\begin{array}{l}\text { Renz et al. } \\
\text { (1987b) }\end{array}$ \\
\hline Cameroon & savannah & 1 & 1 & 0 & 0 & 0 & 0 & 0 & 0 & 0 & 53 & 124 & 70.1 & 70.1 & 124 & 0.7 & 0.7 & all causes & $\begin{array}{l}\text { Renz et al. } \\
(1987 b)\end{array}$ \\
\hline Cameroon & savannah & 1 & 1 & 0 & 0 & 0 & 0 & 0 & 0 & 0 & 923 & 244 & 69.4 & 69.4 & 244 & 0.3 & 0.3 & all causes & $\begin{array}{l}\text { Renz et al. } \\
\text { (1987b) }\end{array}$ \\
\hline Cameroon & savannah & 1 & 1 & 0 & 0 & 0 & 0 & 0 & 0 & 0 & 1,334 & 114 & 89.5 & 89.5 & 114 & 7.6 & 7.6 & all causes & $\begin{array}{l}\text { Renz et al. } \\
\text { (1987b) }\end{array}$ \\
\hline Cameroon & savannah & 1 & 1 & 0 & 0 & 0 & 0 & 0 & 0 & 0 & 578 & 88 & 83.3 & 83.3 & 88 & 3.7 & 3.7 & all causes & $\begin{array}{l}\text { Renz et al. } \\
\text { (1987b) }\end{array}$ \\
\hline Cameroon & savannah & 1 & 1 & 0 & 0 & 0 & 0 & 0 & 0 & 0 & 1,750 & 184 & 94.3 & 94.3 & 184 & 3.4 & 3.4 & oncho & $\begin{array}{l}\text { Duke et al. } \\
\text { (1975) }\end{array}$ \\
\hline Cameroon & savannah & 1 & 1 & 0 & 0 & 0 & 0 & 0 & 0 & 0 & 3,750 & 276 & 92.2 & 92.2 & 276 & 4.4 & 4.4 & oncho & $\begin{array}{l}\text { Duke et al. } \\
\text { (1975) }\end{array}$ \\
\hline Cameroon & savanna & 1 & 1 & 0 & 0 & 0 & 0 & 0 & 0 & 0 & 6,925 & 149 & 98.0 & 98 & 149 & 7.1 & 7.1 & oncho & $\begin{array}{l}\text { Duke et al. } \\
(1975)\end{array}$ \\
\hline $\begin{array}{l}\text { Côte } \\
\text { d'Ivoire }\end{array}$ & forest & 0 & 0 & 0 & 0 & 0 & 0 & 0 & 1 & 0 & & 195 & 74.0 & 74 & 195 & 0.0 & 0.0 & all causes & $\begin{array}{l}\text { Zimmerman } \\
\text { et al.(1992) }\end{array}$ \\
\hline $\begin{array}{l}\text { Côte } \\
\text { d'Ivoire }\end{array}$ & forest & 0 & 0 & 1 & 0 & 0 & 0 & 1 & 1 & 0 & & 74 & 45.5 & 45.5 & 74 & 2.1 & 2.1 & all causes & $\begin{array}{l}\text { Zimmerman } \\
\text { et al.(1992) }\end{array}$ \\
\hline $\begin{array}{l}\text { Côte } \\
\text { d'Ivoire }\end{array}$ & forest & 0 & 0 & 0 & 0 & 0 & 0 & 1 & 1 & 0 & & 248 & 82.6 & 82.6 & 248 & 0.7 & 0.7 & all causes & $\begin{array}{l}\text { Zimmerman } \\
\text { et al.(1992) }\end{array}$ \\
\hline $\begin{array}{l}\text { Côte } \\
\text { d'Ivoire }\end{array}$ & forest & 0 & 0 & 0 & 0 & 0 & 0 & 1 & 0 & 0 & 8,400 & 345 & 70.1 & 70.1 & 286 & 0.0 & 0.0 & oncho & $\begin{array}{l}\text { Dadzie et al. } \\
\text { (1990) }\end{array}$ \\
\hline $\begin{array}{l}\text { Côte } \\
\text { d'Ivoire }\end{array}$ & forest & 0 & 0 & 0 & 0 & 0 & 0 & 1 & 0 & 0 & 8,400 & 140 & 79 & 79 & 111 & 0.0 & 0.0 & oncho & $\begin{array}{l}\text { Dadzie et al. } \\
\text { (1990) }\end{array}$ \\
\hline $\begin{array}{l}\text { Côte } \\
\text { d'Ivoire }\end{array}$ & forest & 0 & 0 & 0 & 0 & 0 & 0 & 1 & 0 & 0 & 6,000 & 268 & 66 & 66 & 207 & 1.1 & 1.1 & oncho & $\begin{array}{l}\text { Dadzie et al. } \\
\text { (1990) }\end{array}$ \\
\hline Côte & forest & 0 & 0 & 0 & 0 & 0 & 0 & 1 & 0 & 0 & 7,200 & 554 & 67.9 & 67.9 & 353 & 0.9 & 0.9 & oncho & $\begin{array}{l}\text { Dadzie et al. } \\
\text { (1990) }\end{array}$ \\
\hline
\end{tabular}


Robert A. Cheke et al.

\begin{tabular}{|c|c|c|c|c|c|c|c|c|c|c|c|c|c|c|c|}
\hline $\begin{array}{l}\text { Côte } \\
\text { d'Ivoire }\end{array}$ & forest & 0 & 0 & 0 & 0 & 0 & 0 & 1 & 0 & 0 & 7,200 & 406 & 62.7 & 62.7 & 321 \\
\hline $\begin{array}{l}\text { Côte } \\
\text { d'Ivoire }\end{array}$ & forest & 0 & 0 & 0 & 0 & 0 & 0 & 1 & 0 & 0 & & 151 & 60.7 & 60.7 & 124 \\
\hline $\begin{array}{l}\text { Côte } \\
\text { d'Ivoire }\end{array}$ & forest & 0 & 0 & 1 & 0 & 0 & 0 & 1 & 1 & 0 & 810 & 62 & 56.6 & 56.6 & 49 \\
\hline $\begin{array}{l}\text { Côte } \\
\text { d'Ivoire }\end{array}$ & forest & 0 & 0 & 0 & 0 & 0 & 0 & 1 & 1 & 0 & 810 & 78 & 67.2 & 67.2 & 66 \\
\hline $\begin{array}{l}\text { Côte } \\
\text { d'Ivoire }\end{array}$ & forest & 0 & 0 & 0 & 0 & 0 & 0 & 1 & 1 & 0 & 1,900 & 95 & 58.2 & 58.2 & 77 \\
\hline $\begin{array}{l}\text { Côte } \\
\text { d'Ivoire }\end{array}$ & forest & 0 & 0 & 0 & 0 & 0 & 0 & 1 & 1 & 0 & 600 & 109 & 48.4 & 48.4 & 88 \\
\hline $\begin{array}{l}\text { Côte } \\
\text { d'Ivoire }\end{array}$ & mosaic & 1 & 1 & 0 & 0 & 0 & 0 & 1 & 0 & 0 & & 120 & 67 & 67 & 120 \\
\hline $\begin{array}{l}\text { Côte } \\
\text { d'Ivoire }\end{array}$ & mosaic & 0 & 0 & 0 & 0 & 0 & 0 & 1 & 0 & 0 & 7,200 & 113 & 69.1 & 69.1 & 84 \\
\hline $\begin{array}{l}\text { Côte } \\
\text { d'Ivoire }\end{array}$ & mosaic & 1 & 1 & 0 & 0 & 0 & 0 & 1 & 0 & 0 & & 116 & 88.5 & 88.5 & 116 \\
\hline $\begin{array}{l}\text { Côte } \\
\text { d'Ivoire }\end{array}$ & savannah & 1 & 1 & 1 & 0 & 0 & 0 & 1 & 1 & 0 & & 404 & 83.5 & 83.5 & 404 \\
\hline $\begin{array}{l}\text { Côte } \\
\text { d'Ivoire }\end{array}$ & savannah & 1 & 1 & 0 & 1 & 0 & 0 & 0 & 0 & 0 & 1,601 & 205 & 73 & 73 & 176 \\
\hline $\begin{array}{l}\text { Côte } \\
\text { d'Ivoire }\end{array}$ & savannah & 1 & 1 & 0 & 0 & 0 & 0 & 0 & 0 & 0 & 1,948 & 154 & 76 & 76 & 128 \\
\hline $\begin{array}{l}\text { Eq. Guinea } \\
\text { (Bioko) }\end{array}$ & forest & 0 & 0 & 0 & 0 & 0 & 0 & 0 & 1 & 0 & 1,954 & 363 & 72.4 & 72.4 & \\
\hline $\begin{array}{l}\text { Eq. Guinea } \\
\text { (Bioko) }\end{array}$ & forest & 0 & 0 & 0 & 0 & 0 & 0 & 0 & 1 & 0 & 864 & 155 & 83.2 & 83.2 & \\
\hline
\end{tabular}

\begin{tabular}{|c|c|c|c|}
\hline 0.3 & 0.3 & oncho & $\begin{array}{l}\text { Dadzie et al. } \\
(1990)\end{array}$ \\
\hline 0.6 & 0.6 & oncho & $\begin{array}{l}\text { Dadzie et al. } \\
(1990)\end{array}$ \\
\hline 0.8 & 0.8 & oncho & $\begin{array}{l}\text { Dadzie et al. } \\
(1990)\end{array}$ \\
\hline 0.0 & 0.0 & oncho & $\begin{array}{l}\text { Dadzie et al. } \\
\text { (1990) }\end{array}$ \\
\hline 0.0 & 0.0 & oncho & $\begin{array}{l}\text { Dadzie et al. } \\
(1990)\end{array}$ \\
\hline 1.3 & 1.3 & oncho & $\begin{array}{l}\text { Dadzie et al. } \\
(1990)\end{array}$ \\
\hline 0.0 & 0.0 & all causes & $\begin{array}{l}\text { Zimmerman } \\
\text { et al.(1992) }\end{array}$ \\
\hline 0.0 & 0.0 & oncho & $\begin{array}{l}\text { Dadzie et al. } \\
(1990)\end{array}$ \\
\hline 9.9 & 9.9 & all causes & $\begin{array}{l}\text { Zimmerman } \\
\text { et al.(1992) }\end{array}$ \\
\hline 7.2 & 7.2 & all causes & $\begin{array}{l}\text { Zimmerman } \\
\text { et al.(1992) }\end{array}$ \\
\hline 4.5 & 4.5 & oncho & $\begin{array}{l}\text { Thylefors et } \\
\text { al. (1978) }\end{array}$ \\
\hline 7.6 & 7.6 & oncho & $\begin{array}{l}\text { Thylefors et } \\
\text { al. (1978) }\end{array}$ \\
\hline 1.3 & 1.3 & all causes & $\begin{array}{l}\text { Mas (1995), } \\
\text { Cheke et al. } \\
\text { (2006) }\end{array}$ \\
\hline 0.6 & 0.6 & all causes & $\begin{array}{l}\text { Mas (1995), } \\
\text { Cheke et al. } \\
\text { (2006) }\end{array}$ \\
\hline
\end{tabular}




\section{Revisiting the Strain Hypothesis in Onchocerciasis}

\begin{tabular}{|c|c|c|c|c|c|c|c|c|c|c|c|c|c|c|c|c|c|c|c|c|c|}
\hline $\begin{array}{l}\text { Eq. Guinea } \\
\text { (Bioko) }\end{array}$ & forest & 0 & 0 & 0 & 0 & 0 & 0 & 0 & 1 & 0 & 421 & 145 & & 79.5 & 79.5 & & & 1.3 & 1.3 & all causes & $\begin{array}{l}\text { Mas (1995), } \\
\text { Cheke et al. } \\
(2006)\end{array}$ \\
\hline $\begin{array}{l}\text { Eq. Guinea } \\
\text { (Bioko) }\end{array}$ & forest & 0 & 0 & 0 & 0 & 0 & 0 & 0 & 1 & 0 & 1,954 & 158 & & 70.1 & 70.1 & & & 1.2 & 1.2 & all causes & Mas (1995) \\
\hline $\begin{array}{l}\text { Eq. Guinea } \\
\text { (Bioko) }\end{array}$ & forest & 0 & 0 & 0 & 0 & 0 & 0 & 0 & 1 & 0 & & 161 & & 85.1 & 85.1 & & & 0.6 & 0.6 & all causes & Mas (1995) \\
\hline $\begin{array}{l}\text { Eq. Guinea } \\
\text { (Bioko) }\end{array}$ & forest & 0 & 0 & 0 & 0 & 0 & 0 & 0 & 1 & 0 & & 154 & & 87.1 & 87.1 & & & 1.2 & 1.2 & all causes & Mas (1995) \\
\hline Ghana & mosaic & 1 & 1 & 1 & 0 & 0 & 0 & 0 & 0 & 0 & & 665 & & & 19.6 & 665 & & 0.09 & 0.09 & oncho & $\begin{array}{l}\text { De Sole et al. } \\
\text { (1992) }\end{array}$ \\
\hline Ghana & savannah & 1 & 1 & 0 & 0 & 0 & 0 & 0 & 0 & 0 & & 133 & & 70.6 & 70.6 & & & 3.5 & 3.5 & all causes & $\begin{array}{l}\text { Zimmerman } \\
\text { et al.(1992) }\end{array}$ \\
\hline Ghana & savannah & 1 & 1 & 0 & 0 & 0 & 0 & 0 & 0 & 0 & 3,330 & 176 & & 88.0 & 88.0 & & & 4.5 & 4.5 & all causes & $\begin{array}{l}\text { Zimmerman } \\
\text { et al.(1992) }\end{array}$ \\
\hline Guinea & savannah & 1 & 1 & 1 & 0 & 0 & 0 & 1 & 1 & 0 & & 215 & & 84.1 & 84.1 & & & 4.4 & 4.4 & all causes & $\begin{array}{l}\text { Zimmerman } \\
\text { et al.(1992) }\end{array}$ \\
\hline Liberia & forest & 0 & 0 & 0 & 0 & 0 & 0 & 1 & 1 & 0 & 5,129 & 94 & 64 & 68.1 & 63.9 & 94 & 3 & 3.19 & 3.0 & oncho & $\begin{array}{l}\text { Frentzel- } \\
\text { Beyme } \\
(1973)\end{array}$ \\
\hline Liberia & forest & 0 & 0 & 0 & 0 & 0 & 0 & 1 & 1 & 0 & 5,129 & 104 & 65 & 62.5 & 62.9 & 104 & 2 & 1.92 & 1.9 & oncho & $\begin{array}{l}\text { Frentzel- } \\
\text { Beyme } \\
(1973)\end{array}$ \\
\hline Liberia & forest & 0 & 0 & 0 & 0 & 0 & 0 & 1 & 1 & 0 & 5,129 & 82 & 56 & 68.3 & 62.9 & 82 & 1 & 1.22 & 1.2 & oncho & $\begin{array}{l}\text { Frentzel- } \\
\text { Beyme } \\
(1973)\end{array}$ \\
\hline Liberia & forest & 0 & 0 & 0 & 0 & 0 & 0 & 1 & 1 & 0 & 2,269 & 45 & 21 & 46.7 & 51.5 & 45 & 1 & 2.22 & 2.2 & oncho & $\begin{array}{l}\text { Frentzel- } \\
\text { Beyme } \\
(1973)\end{array}$ \\
\hline Liberia & forest & 0 & 0 & 0 & 0 & 0 & 0 & 1 & 1 & 0 & 2,269 & 47 & 38 & 80.9 & 70.1 & 47 & 1 & 2.13 & 2.1 & oncho & $\begin{array}{l}\text { Frentzel- } \\
\text { Beyme } \\
(1973)\end{array}$ \\
\hline Liberia & forest & 0 & 0 & 0 & 0 & 0 & 0 & 1 & 1 & 0 & 5,548 & 70 & 48 & 68.6 & 61.9 & 70 & 1 & 1.43 & 1.4 & oncho & $\begin{array}{l}\text { Frentzel- } \\
\text { Beyme } \\
(1973)\end{array}$ \\
\hline Liberia & forest & 0 & 0 & 0 & 0 & 0 & 0 & 1 & 1 & 0 & 3,500 & 45 & 34 & 75.6 & 70.1 & 45 & 4 & 8.89 & 8.8 & oncho & $\begin{array}{l}\text { Frentzel- } \\
\text { Beyme } \\
(1973)\end{array}$ \\
\hline Liberia & forest & 0 & 0 & 0 & 0 & 0 & 0 & 1 & 1 & 0 & 640 & 151 & 105 & 69.5 & 63.9 & 151 & 3 & 1.99 & 1.9 & oncho & $\begin{array}{l}\text { Frentzel- } \\
\text { Beyme } \\
(1973)\end{array}$ \\
\hline Liberia & forest & 0 & 0 & 0 & 0 & 0 & 0 & 1 & 1 & 0 & 1,393 & 85 & 58 & 68.2 & 57.7 & 85 & 4 & 4.71 & 4.7 & oncho & $\begin{array}{l}\text { Frentzel- } \\
\text { Beyme } \\
(1973)\end{array}$ \\
\hline Liberia & forest & 0 & 0 & 0 & 0 & 0 & 0 & 0 & 1 & 0 & 583 & 80 & 56 & 70.0 & 62.9 & 80 & 1 & 1.25 & 1.3 & oncho & $\begin{array}{l}\text { Frentzel- } \\
\text { Beyme } \\
(1973)\end{array}$ \\
\hline
\end{tabular}


Robert A. Cheke et al.

\begin{tabular}{|c|c|c|c|c|c|c|c|c|c|c|c|c|c|c|c|c|c|c|c|c|c|}
\hline Liberia & forest & 0 & 0 & 0 & 0 & 0 & 0 & 0 & 1 & 0 & 583 & 23 & 17 & 73.9 & 76.3 & 23 & 0 & 0.0 & 0.0 & oncho & $\begin{array}{l}\text { Frentzel- } \\
\text { Beyme } \\
(1973)\end{array}$ \\
\hline Liberia & forest & 0 & 0 & 0 & 0 & 0 & 0 & 0 & 1 & 0 & 583 & 25 & 16 & 64.0 & 70.1 & 25 & 0 & 0.0 & 0.0 & oncho & $\begin{array}{l}\text { Frentzel- } \\
\text { Beyme }\end{array}$ \\
\hline Liberia & forest & 0 & 0 & 0 & 0 & 0 & 0 & 0 & 1 & 0 & 583 & 49 & 31 & 63.3 & 64.9 & 49 & 1 & 2.04 & 2.0 & oncho & $\begin{array}{l}\text { Frentzel- } \\
\text { Beyme } \\
(1973)\end{array}$ \\
\hline Liberia & forest & 0 & 0 & 0 & 0 & 0 & 0 & 0 & 1 & 0 & 583 & 70 & 28 & 40.0 & 55.7 & 70 & 1 & 1.43 & 1.4 & oncho & $\begin{array}{l}\text { Frentzel- } \\
\text { Beyme } \\
(1973)\end{array}$ \\
\hline Liberia & forest & 0 & 0 & 0 & 0 & 0 & 0 & 0 & 1 & 0 & 239 & 43 & 12 & 27.9 & 37.1 & 43 & 1 & 2.32 & 2.2 & oncho & $\begin{array}{l}\text { Frentzel- } \\
\text { Beyme } \\
(1973)\end{array}$ \\
\hline Liberia & forest & 0 & 0 & 0 & 0 & 0 & 0 & 0 & 1 & 0 & 239 & 59 & 34 & 57.6 & 55.7 & 59 & 0 & 0.0 & 0.0 & oncho & $\begin{array}{l}\text { Frentzel- } \\
\text { Beyme } \\
(1973)\end{array}$ \\
\hline Liberia & forest & 0 & 0 & 0 & 0 & 0 & 0 & 0 & 1 & 0 & 239 & 71 & 50 & 70.4 & 58.8 & 71 & 4 & 5.63 & 5.6 & oncho & $\begin{array}{l}\text { Frentzel- } \\
\text { Beyme } \\
(1973)\end{array}$ \\
\hline Liberia & forest & 0 & 0 & 0 & 0 & 0 & 0 & 1 & 1 & 0 & 2,100 & 300 & & 74.0 & 74.0 & 76 & 3 & 3.95 & 4.0 & all causes & $\begin{array}{l}\text { Albiez et al. } \\
\text { (1981) }\end{array}$ \\
\hline Nigeria & mosaic & 1 & 1 & 0 & 0 & 0 & 0 & 0 & 1 & 0 & & 859 & 259 & 30.2 & 30.2 & 859 & 35 & 4.07 & 4.1 & oncho & $\begin{array}{l}\text { Umeh et al. } \\
\text { (1996) }\end{array}$ \\
\hline Nigeria & savannah & 1 & 1 & 0 & 0 & 0 & 0 & 0 & 0 & 0 & & 6,831 & & 72.0 & 72.0 & 6,831 & 111 & 1.62 & 1.3 & oncho & $\begin{array}{l}\text { Abiose et } \\
\text { al.(1994) }\end{array}$ \\
\hline Senegal & savannah & 1 & 1 & 0 & 0 & 0 & 0 & 0 & 0 & 0 & & 212 & & 62.2 & 62.2 & & & 0.4 & 0.4 & all causes & $\begin{array}{l}\text { Zimmerman } \\
\text { et al.(1992) }\end{array}$ \\
\hline $\begin{array}{l}\text { Sierra } \\
\text { Leone }\end{array}$ & mosaic & 0 & 0 & 1 & 0 & 1 & 0 & 0 & 1 & 0 & & 803 & & 70.5 & 70.5 & 803 & 19 & 2.37 & 2.4 & oncho & $\begin{array}{l}\text { McMahon et } \\
\text { al.(1988) }\end{array}$ \\
\hline $\begin{array}{l}\text { Sierra } \\
\text { Leone }\end{array}$ & mosaic & 0 & 1 & 1 & 0 & 1 & 0 & 0 & 1 & 0 & & 190 & & 85.6 & 85.6 & & & 3.8 & 3.8 & all causes & $\begin{array}{l}\text { Zimmerman } \\
\text { et al.(1992) }\end{array}$ \\
\hline $\begin{array}{l}\text { Sierra } \\
\text { Leone }\end{array}$ & mosaic & 0 & 0 & 1 & 0 & 1 & 0 & 0 & 1 & 0 & & 132 & & 88.5 & 88.5 & & & 5.5 & 5.5 & all causes & $\begin{array}{l}\text { Zimmerman } \\
\text { et al.(1992) }\end{array}$ \\
\hline $\begin{array}{l}\text { Sierra } \\
\text { Leone }\end{array}$ & mosaic & 0 & 0 & 1 & 0 & 1 & 0 & 0 & 1 & 0 & & 174 & & 81.0 & 81.0 & & & 2.2 & 2.2 & all causes & $\begin{array}{l}\text { Zimmerman } \\
\text { et al.(1992) }\end{array}$ \\
\hline $\begin{array}{l}\text { Sierra } \\
\text { Leone }\end{array}$ & mosaic & 0 & 0 & 1 & 0 & 1 & 0 & 0 & 1 & 0 & & 129 & & 81.8 & 81.8 & & & 1.6 & 1.6 & all causes & $\begin{array}{l}\text { Zimmerman } \\
\text { et al.(1992) }\end{array}$ \\
\hline $\begin{array}{l}\text { Sierra } \\
\text { Leone }\end{array}$ & mosaic & 0 & 1 & 0 & 0 & 1 & 0 & 0 & 0 & 0 & & 134 & & 78.9 & 78.9 & & & 0.0 & 0.0 & all causes & $\begin{array}{l}\text { Zimmerman } \\
\text { et al.(1992) }\end{array}$ \\
\hline $\begin{array}{l}\text { Sierra } \\
\text { Leone }\end{array}$ & mosaic & 1 & 1 & 1 & 0 & 1 & 0 & 0 & 1 & 0 & & 150 & & 78.7 & 78.7 & & & 2.7 & 2.7 & all causes & $\begin{array}{l}\text { Zimmerman } \\
\text { et al.(1992) }\end{array}$ \\
\hline $\begin{array}{l}\text { Sierra } \\
\text { Leone }\end{array}$ & mosaic & 1 & 1 & 1 & 0 & 0 & 0 & 1 & 0 & 0 & & 611 & & 51.7 & 51.7 & 611 & & & 2.4 & oncho & $\begin{array}{l}\text { McMahon et } \\
\text { al.(1988) }\end{array}$ \\
\hline
\end{tabular}


Revisiting the Strain Hypothesis in Onchocerciasis

\begin{tabular}{|c|c|c|c|c|c|c|c|c|c|c|c|c|c|c|c|c|c|}
\hline Togo & forest & 0 & 0 & 1 & 0 & 0 & 0 & 0 & 0 & 0 & & 318 & 40.5 & 318 & $0.37^{*}$ & oncho & $\begin{array}{l}\text { De Sole et al. } \\
\text { (1992) }\end{array}$ \\
\hline Togo & forest & 0 & 0 & 1 & 0 & 0 & 0 & 1 & 0 & 0 & & 315 & 62.4 & 315 & $1.11^{*}$ & oncho & $\begin{array}{l}\text { De Sole et al. } \\
\text { (1992) }\end{array}$ \\
\hline Togo & forest & 0 & 0 & 1 & 0 & 0 & 1 & 1 & 0 & 0 & & 159 & 38.5 & 159 & $0.29 *$ & oncho & $\begin{array}{l}\text { De Sole et al. } \\
\text { (1992) }\end{array}$ \\
\hline Togo & mosaic & 1 & 0 & 1 & 0 & 0 & 1 & 1 & 0 & 0 & 2,056 & 224 & 33.0 & 224 & $0.3^{*}$ & oncho & $\begin{array}{l}\text { De Sole et al. } \\
\text { (1992) }\end{array}$ \\
\hline Togo & mosaic & 1 & 0 & 1 & 0 & 0 & 0 & 1 & 0 & 0 & & 537 & 19.1 & 537 & $0.11^{*}$ & oncho & $\begin{array}{l}\text { De Sole et al. } \\
\text { (1992) }\end{array}$ \\
\hline Togo & mosaic & 1 & 0 & 0 & 0 & 0 & 1 & 1 & 0 & 0 & & 543 & 7.5 & 543 & $0.04 *$ & oncho & $\begin{array}{l}\text { De Sole et al. } \\
\text { (1992) }\end{array}$ \\
\hline Togo & savannah & 1 & 1 & 1 & 0 & 0 & 1 & 0 & 0 & 0 & & 649 & 64.0 & 649 & $2.36^{*}$ & oncho & $\begin{array}{l}\text { De Sole et al. } \\
\text { (1992) }\end{array}$ \\
\hline Togo & mosaic & 1 & 1 & 1 & 0 & 0 & 1 & 0 & 0 & 0 & & 821 & 54.8 & 821 & $1.3^{*}$ & oncho & $\begin{array}{l}\text { De Sole et al. } \\
(1992)\end{array}$ \\
\hline
\end{tabular}

dam $=S$. damnosum s.str.; sirb $=S$. sirbanum; squa $=S$. squamosum; soub $=$ S. soubrense $;$ leon $=$ S. leonense $;$ beffa $=$ Beffa form of S. soubrense; sanc $=S$. sanctipauli s.l.; yah $=S$. yahense $;$ men $=S$. mengense $;$ with $1=$ cytoform present; zeroes = cytoform absent; $+\mathrm{ve}=$ positive; ATP = annual transmission potential (no. of L3/person/year); exam. = examined; $\mathrm{mf}=$ microfilariae; oncho = onchocerciasis; prev. = prevalence (in \%); Stand. = standardised; *denotes blindness prevalence which is reported here as 'bilateral' blindness' but for which the authors did not specify if the values refer to bilateral blindness or not (these data were omitted in a subsequent analyses which did not yield different results; see 3.3. Bilateral blindness, in the main text). 
Table 3 The percentages of microfilariae (mf) that had emerged after different durations of incubation as a percentage of the total that emerged after 24 hours and the percentages of positive skin snips detected after different durations as a percentage of the total number positive after 24 hours (Collins et al., 1980).

\begin{tabular}{lll} 
Hours & \% mf emerged & $\begin{array}{l}\text { \% total positives } \\
\text { detected }\end{array}$ \\
\hline 0.5 & 60.7 & \\
1 & 72.1 & 90.3 \\
2 & 88.5 & \\
3 & 95.1 & \\
4 & 100 & 97.7 \\
8 & & 99.2 \\
24 & 100 & 100 \\
\hline
\end{tabular}

The data shown correspond to Study I of Collins et al. (1980), in which snips were incubated on microscope slides. After incubation and enumeration of emerged microfilariae, snips were fixed in $10 \%$ formalin, serially sectioned at $7 \mu$, stained with haematoxylin and eosin, and the microfilariae remaining in the tissue were counted. 


\section{Figure Legends}

Figure 1 (A) Vector (female Simulium damnosum s.l.) and (B) life cycle of Onchocerca volvulus; (C-F) disease manifestations associated with onchocerciasis: (C) head nodule in a child; (D) chronic uveitis with secondary cataract in right eye and sclerosing keratits in left eye; (E) child leading a blind man; (F) skin depigmentation in the shin (leopard skin). In addition to skin and eye disease, onchocerciasis is also associated with human excess mortality and epilepsy (Little et al., 2004b; Walker et al., 2012; Colebunders et al., 2019). Credits: (A) Rolf Garms; (B) Basáñez et al. (2006) for life cycle and Maria-Gloria Basáñez for microfilariae, L1 larva and L3 larva; (C \& F) Simon J. O’Hanlon; (D) Adrian D. Hopkins; (E) Poppy H.L. Lamberton.

Figure 2 Prevalence of blindness (\%) according to habitat. (A) raw data with no weights: mean percentage for forest $=2.02 \pm 0.36$ (S.E.), mosaic $=2.04 \pm 0.58$, savannah $=2.81 \pm$ 0.47 ; (B) raw data weighted by sample sizes: mean percentage for forest $=1.76 \pm 0.37$, mosaic $=1.49 \pm 0.38$, savannah $=1.89 \pm 0.26 ;(C)$ angular-transformed data with no weights: mean de-transformed percentage blindness for forest $=1.41 \pm 0.30$, mosaic $=1.25 \pm 0.46$, savannah $=1.92 \pm 0.47$; (D) angular-transformed data, weighted by sample size: mean detransformed percentage blindness for forest $=1.39 \pm 0.32$; mosaic $=0.99 \pm 0.28$; savannah $=$ $1.50 \pm 0.24$. Error bars are standard errors.

Figure 3 De-transformed weighted mean blindness prevalence for forest, mosaic and savannah habitats based on blindness due to onchocerciasis only. Mean de-transformed blindness prevalence for forest $=0.79 \pm 0.36$ (S.E.), mosaic $=0.84 \pm 0.26$, savannah $=1.19 \pm$ 0.23. Error bars are standard errors.

Figure 4 Box-and-whisker plots for the prevalence of blindness in forest habitats only according to country. The horizontal dark black lines within the boxes represent the median blindness prevalence for each country; the lower and upper borders of the box are the lower 
$(25 \%)$ and upper $(75 \%)$ quartiles of the data; the whiskers represent the minimum and maximum values; marker (open circle in Liberia) represents an outlier.

Figure 5 Relationships between annual transmission potential (ATP, no. L3/person/year) and blindness prevalence for (A) forest including data from southern Côte d'Ivoire; (B) forest excluding data from southern Côte d'Ivoire; (C) savannah. Dotted lines are 95\% confidence intervals. Note logarithmic scale on the x-axis.

Figure 6. Relationships between prevalence of microfilariae and prevalence of blindness for (A) forest including data from southern Côte d'Ivoire; (B) forest excluding data from southern Côte d'Ivoire; (C) savannah. Dotted lines are 95\% confidence intervals. 